\title{
Woodlands of the past - The excavation of wetland woods at Zwolle-Stadshagen (the Netherlands): Reconstruction of the wetland wood in its environmental context
}

\author{
M.J. Kooistra' ${ }^{1,}$, L.I. Kooistra ${ }^{2}$, P. van Rijn ${ }^{2} \&$ U. Sass-Klaassen ${ }^{3}$ \\ 1 International Soil Reference and Information Centre (ISRIC), P.0. Box 353, 6700 AJ Wageningen, the Netherlands. Previously Alterra, Green \\ World Research, Wageningen, the Netherlands. \\ 2 Biax Consult, Hogendijk 134, 1506 AL Zaandam, the Netherlands. \\ 3 Netherlands Centre for Dendrochronology, Ring Foundation, P.0. Box 1600, 3800 BP Amersfoort, the Netherlands and Wageningen \\ University, Environmental Science, Forest Ecology and Forest Management Group, P.0. Box 342, 6700 AH Wageningen, the Netherlands. \\ * Corresponding author. Email: maja.kooistra@wur.nl
}

Manuscript received: June 2005; accepted: January 2006

\begin{abstract}
Information on the vegetation and landscape history of a region is often limited, and available data are hard to interprete. A concept is presented here on how a more comprehensive picture of the structure and development of landscapes and vegetations of the past can be gained by integrating the information of several disciplines. Archaeological field methods have been combined with methods used in landscape studies (geology, soil science, micromorphology) and vegetation studies (ecology, palynology and dendrochronology).

This concept has been applied and tested during an integrated study of a buried woodland at Zwolle-Stadshagen (Province of Overijssel, the Netherlands). Many large wood remnants were found in a peat layer preserved below a thick clay deposit. The wood remnants were dated by using dendrochronology to the period between ca. $150 \mathrm{BC}$ and AD 580 (ca. 2200 - $1400 \mathrm{cal}$. BP). Two phases could be distinguished in the development of the peat. The woodland consisted of a closed stand with ash, alder and oak as main species, in the first phase mostly resembling an alder carr, and in the second one the near-extinct Filipendulo-Alnetum Passage et Hofmann 1968. No evidence of exploitation of the woodland by man nor of animal foraging was found.

The followed integrated procedure has led to a more substantiated reconstruction of the palaeo-environment with its wetland wood, but also of the influence of human activities on the palaeo-landscape and its woodlands, that could not have been obtained otherwise.
\end{abstract}

Keywords: landscape reconstruction, micromorphology, palynology, vegetation reconstruction, wetland wood, wood analyses

\section{Introduction}

There is a growing demand for more detailed information on former landscapes and vegetation structures as well as on the underlying determining factors. Apart from applications in earth sciences and archeology, the information is increasingly being used as reference for planning activities in the rural environment and to analyze changes due to external site conditions, for example hydrological changes that may be triggered by large-scale variations in climate conditions.

Nowadays ecologists, palynologists and dendrochronologists have raised questions about the interpretation of palynological datasets from archaeological and palaeo-ecological contexts for landscape reconstruction. Since the establishment of palynology at the beginning of the 20th century, the discipline has been used to collect information on the history of vegetations. These datasets, however, do not provide enough information to answer the increasingly detailed questions about the structure and genesis of (pre)historic landscapes and the underlying causes of changes. Moreover, there is a revival in the discussion about the interpretation of palynological data. An important stimulus to this revival comes from the publications of Vera $(1997,2000)$, who, on the basis of mostly palynological data, comes to the conclusion that the vegetation on 
the Northwest European continent during the Atlantic existed of an open park-like landscape and not of closed forests. Several biologists, palynologists, botanists and archaeozoölogists disagreed with Vera's views (including Van den Bremt et al., 1998; Zeiler \& Kooistra, 1998), but arguments for and against could not be consolidated for lack of adequate studies. Palynologists calibrate their findings mainly by experimental field studies on the actual relationships between pollen production and vegetation (e.g. Andersen, 1970, 1973; Birks \& Gordon, 1985; Gaillard et al., 1994; Hicks, 2001). Palynological data of past periods have been interpreted on the basis of knowledge acquired in such studies. However, there is an inherent risk in the use of recent and subrecent vegetation types as references for earlier ones, since it is imaginable that types of vegetation have existed in the past that no longer exist. Also, no detailed information on decomposition rates under varying conditions, inclusive selective consumption of pollen by soil fauna, is available. Ecological data should therefore be calibrated against independent sources of similar age and location. To get a more comprehensive picture about the structure and development of past landscapes and vegetations a concept is needed in which independent data sets from different disciplines within earth sciences, archaeology and botany can be tested against each other. In the past the employment of different disciplines generally occurred independently of each other. Consequently, results could not always be compared, permitting only a restricted integration of data. In order to obtain such independent data sets a proper field survey of the disciplines involved, coupled with an adequate sampling strategy is required. On the other hand, undisturbed, wellpreserved deposits in which remnants of former woodlands are present, which also can be properly excavated, are rare.

Fortunately, such an opportunity presented itself in 2000. During preparatory work preceding building activities for a new urban extension of the town of Zwolle (Province of Overijssel, the Netherlands), many large remnants of sub-fossil wood were found in a peat layer preserved below a clay deposit. The subsoil in which this peat layer was found seemed undisturbed and the extent of the area was such that a buried woodland could be expected. Preliminary dendrochronological dating of three tree remnants indicated that this woodland dates to approximately $1 \mathrm{BC} / \mathrm{AD} 1$ and it was expected that from an integrated study of the subsoil detailed information on the development of the vegetation in its environmental context just before and after the start of our Era could be obtained.

Archaeologists of Zwolle were particularly interested in the period from 800 BC until AD 1000 (ca. 2800 - 950 cal. BP) in relation to the disappearance of the Bronze Age habitation in the area around Zwolle. Van Geel et al. (1996, 1998) have proposed a change to a colder and wetter climate, not only in this part of the country but also elsewhere in low lying regions in the Netherlands. The Archaeological Service of Zwolle decided to a fully-fledged excavation of the buried woodland, as this might give insight into the local conditions in relation to the interaction between the local landscape and the occupation history of the area and whether or how people may have exploited the woodlands.

For this occasion the idea of an integrated approach was developed. The natural woodland had to be excavated according to the normally applied archaeological methods. At the same time researchers from different disciplines within earth sciences, archaeology and botany had to join efforts to set up a registration and sampling strategy in order to create data sets that could be mutually related to such a level that the palaeo-landscape and vegetation structure of this buried woodland could be reconstructed with general acceptance. The participating disciplines were (1) physical geography, soil science and micromorphology, in order to assemble information on the abiotic landscape development and the hydrology, (2) ecology including palynology, archaeobotany and wood analyses, to gather information on the vegetation including its structure and development, and (3) dendrochronology, for the absolute dating of the wood remnants, the assessment of the population dynamics of the key species in the woodland and for detection and evaluation of local and regional factors that influenced tree growth and population dynamics. Each discipline had to provide independent data and interpretations of the data on the structure, composition and changes in the vegetation in its environmental context, that also could be used to test the interpretations of the others and to refine, complement and strengthen each other's results (Kooistra \& Kooistra, 2003).

Consequently, the following research objectives were formulated for the excavation of the buried woodland at Zwolle-Stadshagen:

1. Reconstruction of the landscape in which the woodland has grown.

2. Reconstruction of the original vegetation, its structure and its development.

3. Chronology of the environmental development and causes of change.

4. Tracing human presence in the reconstructed landscape.

5. Evaluation of the integrated concept.

The results of this study are presented in two articles, both published in this issue. This article deals with the reconstruction of the palaeo-environment and its woodlands together with the contemporary evidence of human activity in the study area. In the second article the growth patterns and population dynamics of the key tree species of the woodlands, oak and ash, are presented and discussed in relation to changes in site ecology and the triggering (climate) factors behind. 


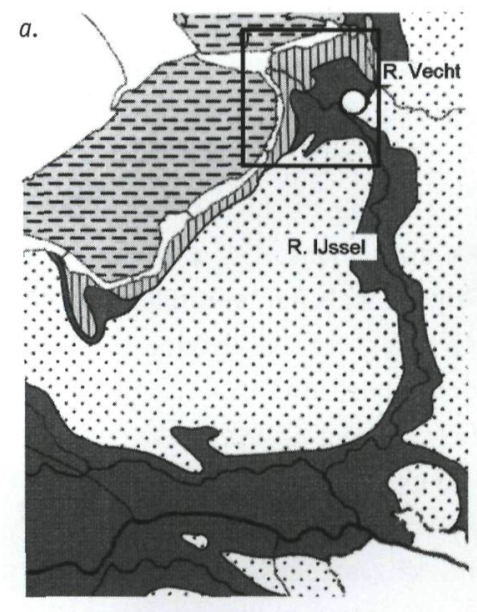

Pleistocene

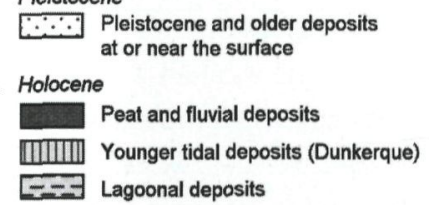

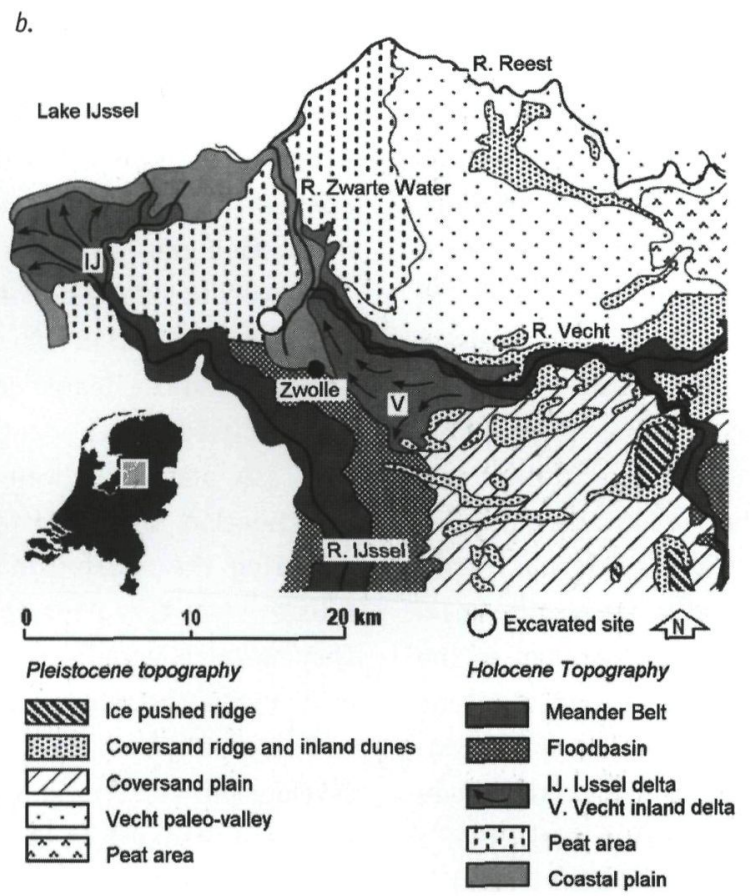

Fig. 1. Maps of a. The geological distribution of Pleistocene and Holocene deposits in the centre of the Netherlands after Zagwijn (1991); and b. The geomorphological setting of the northwestern part of the Province of Overijssel after Wolfert (2001).

\section{Site description}

The excavated woodland is situated in Stadshagen, an area northwest of the town Zwolle in the Mastenbroek Polder in the northwest of the Province of Overijssel (see Figs 1 and 2). The woodland remnants occur in peaty Holocene deposits that can be found between $0.4-1.2 \mathrm{~m}$ below surface on top of Pleistocene sands, about $600-800 \mathrm{~m}$ west of the river Zwarte Water. The Pleistocene sands are Weichselian aeolian coversands (Boxtel Formation). The Pleistocene surface had a considerable relief and consisted locally of NW-SE oriented elongated ridges alternating with depressions, on top of a system of braided river beds, with a slight west-facing slope (Kuijer \& Rosing, 1994; Wolfert, 2001).

With the start of the warmer Holocene climate, about 10,000 years ago, vegetation cover became more dense, aeolian activity ceased and soils started to develop. The mild climate resulted in a rise in sea-level and the coastline gradually moved inland. This took several thousands of years. The sealevel rise caused an increase in groundwater levels inland from the coastline. When the groundwater level reached the surface, peat started to develop. In this Basal Peat wetland woods often developed. The peat growth reached the lower parts of the study area from the northwest in the Late Subboreal around $1250 \mathrm{BC}$ (ca. $3200 \mathrm{cal}$. BP) and continued through the Roman Period. At the start of the early Middle Ages, around AD 500 (ca. 1400 cal. BP), the peat expansion stopped (Zagwijn, 1986). In the study area the peat became covered by a clay deposit which may be either fluviatile or marine. Two rivers were important in this area, the IJssel and the Vecht. The IJssel, that presumably became active round $1950 \mathrm{cal}$. BP (Van de Meene, 1979), became increasingly more important.
During the period of extensive peat growth sedimentation was very limited, but from the early Middle Ages onwards, riversediments from the IJssel began to accumulate (Lanting \& Mook, 1977; Van de Meene, 1979; Zagwijn, 1986). After the start of

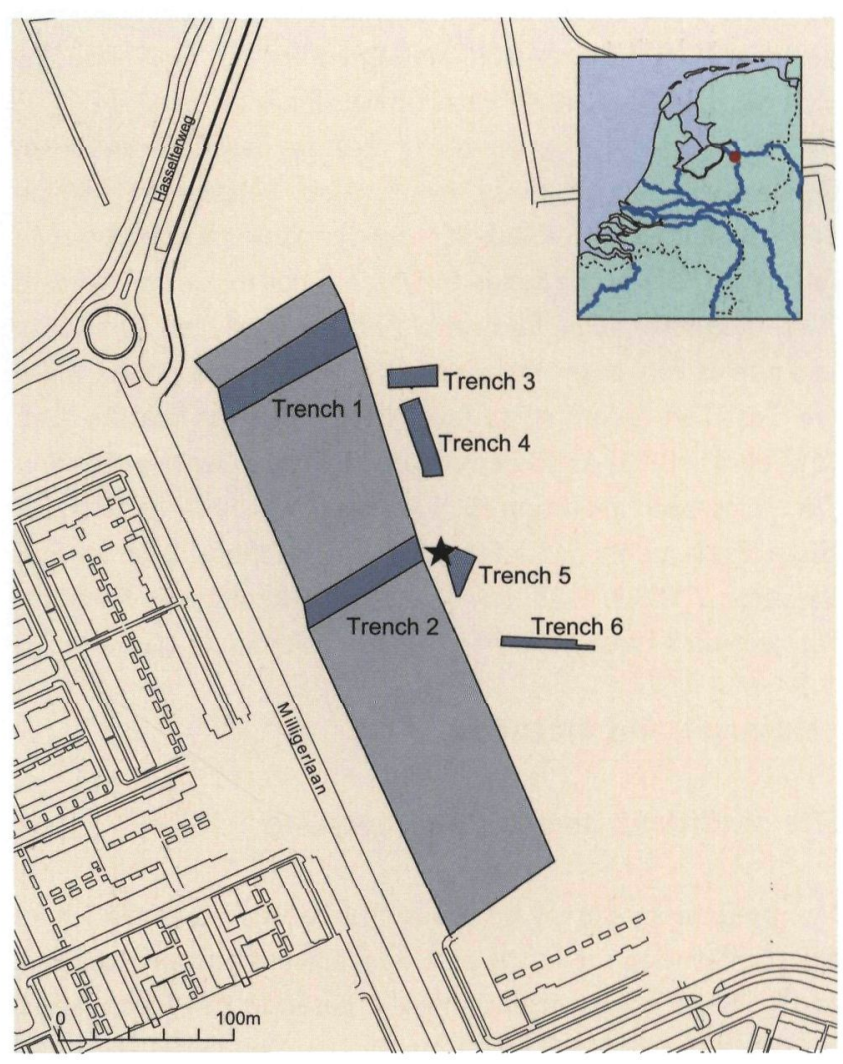

Fig. 2. Overview of the position of the trenches and location of the excavation near the town of Zwolle, the Netherlands.

* Location of the profile where samples were taken for micromorphological and palynological research. 
reclamation activities along the IJssel around $\mathrm{AD} 1100$ (ca. 850 cal. BP), its meander belt was formed (Kuijer \& Rosing, 1994). On the contrary, the influence of the Vecht diminished during the Holocene and several abandoned river beds can be found east and southeast of Zwolle (Kuijer \& Rosing, 1994; Wolfert, 2001). From the 14th century onwards the influence of the sea on the IJsselmeer area increased, as the connection with the North Sea widened. Around AD 1600 (ca. 350 cal. BP) seawater reached the area northwest of Zwolle and marine clays were laid down along the Zwarte Water (Wiggers, 1955; Ente, 1971). The sea was cut off by the construction of an enclosure dam in 1932 and no sedimentation from the sea has taken place in this area since (Eilander \& Heijink, 1990; Kuijer \& Rosing, 1994).

In Figure 1 two maps are given, elucidating the local situation. Figure $1 \mathrm{a}$ is a section of a geological map of the Netherlands showing the general distribution of the Pleistocene and Holocene deposits at or near the surface (Zagwijn, 1986). Figure $1 \mathrm{~b}$ shows the geomorphological setting of the study area in more detail (Wolfert, 2001, based on Ente et al., 1965). In both maps the location of the excavated wetland wood is given. From Figure 1a it can be observed that the excavated wetland wood occurred in Holocene deposits near the boundary with Pleistocene deposits. Figure $1 \mathrm{~b}$ shows the local situation in more detail. Based on this figure the wetland wood is present in peat below marine deposits. Kuijer \& Rosing (1994), however, place the boundary of marine and fluvial deposits just north of the excavated wetland wood. In that case the excavated site is covered with fluvial deposits.

The soils present in the study area are described as fluvial floodplain soils with a clay layer on top. Between $40-80 \mathrm{~cm}$ depth a peaty layer about $15-50 \mathrm{~cm}$ thick can be observed on top of Pleistocene sands in which a podzol has developed. These soils have AC profiles, with a weakly developed A1 horizon and a relatively high watertable (Kuijer \& Rosing, 1994). They are classified according to the Dutch soil classification (Ten Cate et al., 1995) as poldervaaggronden (Rn47wp); in the Soil Taxonomy, second edition (Soil Survey Staff, 1999), as ThaptoHistic Fluvaquents and after the World Reference Base for Soil Resources (I.S.S.S.-ISRIC-F.A.0., 1998) as Thaptohistic Fluvisols. For centuries these soils were used as permanent pastures.

\section{Material and Methods}

\section{Site conditions, samples and sampling}

In a preliminary survey a terrain of 3 ha was examined where the clay layer on top of the peat was removed and two trenches of $15 \times 80 \mathrm{~m}$ were studied in detail. Based on the information obtained and the quality of the woody remnants, four new trenches with artificially reduced groundwater levels were excavated from the surface down to the base of the buried woodland with a total area of ca. $1270 \mathrm{~m}^{2}$ (Fig. 2). In the trenches the remnants of stumps and trunks of the former trees were present in their original positions (Fig. 3). The base and top of the peat as well as all recognizable wood remnants were leveled relative to Dutch 0.D. (N.A.P.) and their position determined three-dimensionally in a local grid. Each wood remnant was numbered and identified to the species. A short description was made on its dimensions, the morphological characteristics (trunk, tree top, branch, roots, unidentifiable) including information about the presence and location of lateral branches and the degree of decomposition. All wood remnants were sampled for lab identification and all larger remnants of oak, ash and alder were sampled for dendrochronological investigation. For the latter a chain-saw was used.

During the excavation 45 soil samples of approximately 5 litres were taken for analyses of seeds and insects/mites. They were collected near tree trunks to be able to compare results with the information from corresponding trees.

The profile walls of the trenches were studied and their development and stratigraphy determined. The profile development and sequence in the four studied trenches was uniform, only the thickness of the peat layer and its base level showed slight variation, generally a few centimetres, with a maximum of 30 centimetres. Therefore, one location for detailed sampling was selected in trench 5, Westprofile (see Fig. 2). The selected soil profile was studied in detail and samples for micromorphological and palynological research were collected at the same time next to each other to enable optimal integration of the results.

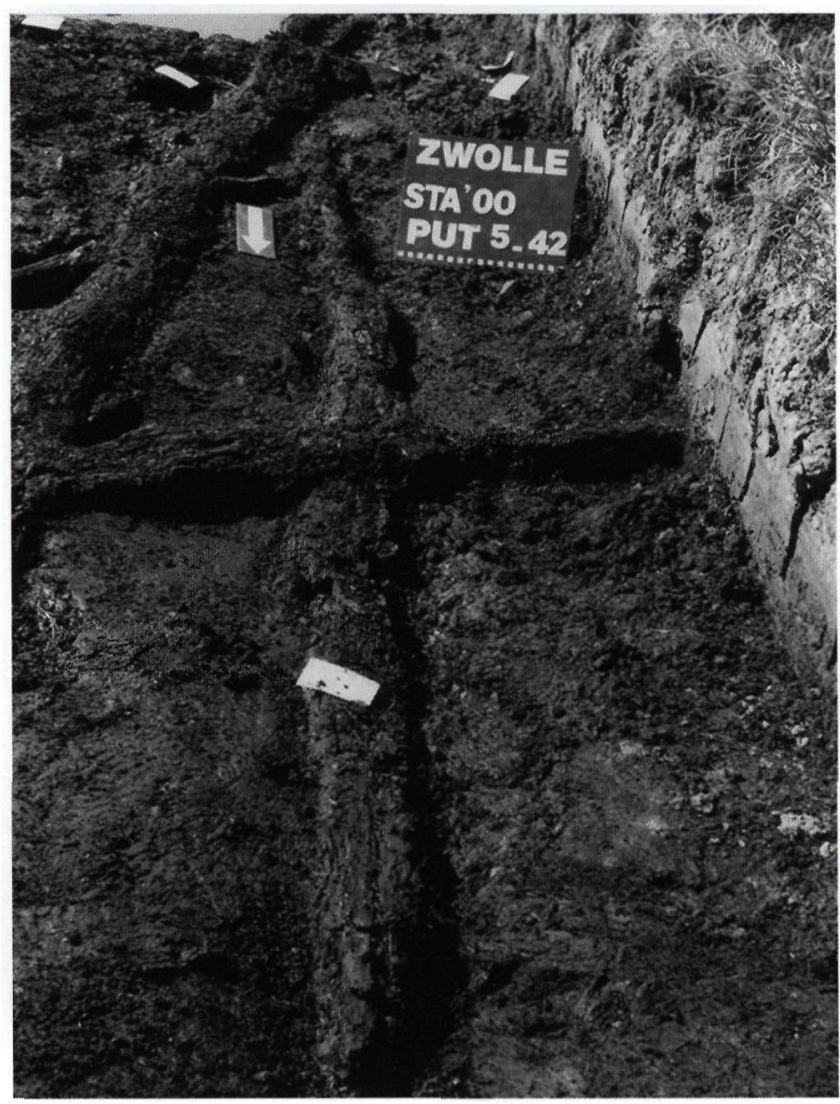

Fig. 3. Peat layer with wood remnants. 


\section{Micromorphological analysis}

The selected soil profile was described after the Soil Taxonomy (Soil Survey Staff, 1999) and the colours refer to the moist conditions according to the Munsell Soil Color Charts (1975).

Grain-size analyses were performed by laser diffraction with a Coulter LS230 apparatus (Buurman et al., 2001).

The micromorphological samples cover a depth of $70 \mathrm{~cm}$, from $57-126 \mathrm{~cm}$ - Dutch 0.D. The samples were collected continuously in tins of $15 \times 8 \times 2.5 \mathrm{~cm}$. The undisturbed micromorphological samples were freeze-dried to prevent shrinkage of the samples, impregnated with a colourless unsaturated polyester resin and hardened by gamma radiation. The thin sections of $8 \times 15 \mathrm{~cm}$ with a thickness of $25 \mu \mathrm{m}$ were made from the undisturbed core of the hardened blocks (Jongerius \& Heintzberger, 1975; Bisdom \& Schoonderbeek, 1983). This size is required to be representative for the soil material studied and allows extrapolation of the analysed processes to the soil horizons studied. The thin sections were analysed with a polarization research microscope with magnifications up to $\times 200$. In thin sections generally more layers and/or transitions can be distinguished. They will be described successively starting with the deepest layer in order to study processes chronologically from old to young. The data recording consists of two parts: 1 . analyses of the parent material and relevant features and 2. interpretation of these data in terms of processes that occurred, their sequence and interactions. Overviews of procedures for the reconstruction of processes dealing with the genesis of the landscape, the soils and human impact are given in Kooistra (1990, 1991).

\section{Palynological analysis}

The palynological samples were taken within one meter from the micromorphological samples in two overlapping pollen monolith tins. They cover a depth of $60.5 \mathrm{~cm}$, from 54 to $114.5 \mathrm{~cm}$ - Dutch 0.D. Under laboratory conditions, twenty subsamples of 1 to $2 \mathrm{~cm} 3$ were taken. The section containing peat, between 54 and $88 \mathrm{~cm}$ - Dutch O.D. was sampled every other centimeter, while from the underlying coversand subsamples were taken at five-centimeter intervals. The subsamples were treated according to Erdtman (1960) and Fægri et al. (1989). This method was modified by the addition of tablets containing known amounts of exotic Lycopodium spores to be able to calculate the pollen concentrations. Eight samples were selected for detailed analysis. These derived from the following strata: one from the sandy humous layer below the peat $(84 \mathrm{~cm}-0 . D$.), six from the peat $(80,78,74$, $70,66$ and $62 \mathrm{~cm}-0 . D$.$) and one from the base of the clay$ layer on top of the peat $(60 \mathrm{~cm}-0 . D$.$) . No samples were$ selected from the base of the sandy humous layer and the underlying podzol, as the quantity of pollen was low and their preservation poor. In the sample slides the microfossils were counted until 300 tree pollen had been recorded. This tree pollen constitutes the pollen sum. Besides pollen and spores, also other palynomorphs were counted, such as algae and soil fungi. For the identification of pollen and spores the usual reference works were consulted (Fægri et al., 1989; Punt, 1976; Punt \& Clarke, 1980, 1981, 1984; Punt et al., 1988; Punt \& Blackmore, 1991; Punt et al., 1995; Moore et al., 1991), as well as the reference collection of BIAX Consult.

The results of palynological analyses are presented in pollen diagrams made up of a series of curves representing identified plant species, in which the y-axis shows the depth in cm - 0.D. and the $\mathrm{x}$-axis the species occurrences in percentages. The first curve shows the so-called AP:NAP ratio, the ratio (in \%) between pollen from trees and shrubs (AP, Arboreal Pollen) and pollen from herbs (NAP, Non-Arboreal Pollen), excluding water plants, mosses and ferns. The second curve shows the pollen concentration. The species curves are arranged in different categories: exotics, regional woodland species, local woodland species, marshland species, open-water species, bog/heathland species, meadowland species, cereals, ruderals and miscellaneous.

\section{${ }^{14} \mathrm{C}$ dating}

Bulk samples for ${ }^{14} \mathrm{C}$ dates were collected from the pollen monolith tins. The Groningen calibration programme (version Cal25) was used for calibration (Van der Plicht, 1993). The degree of smoothing of the calibration curve was based on Törnqvist \& Bierkens (1994). Dates are presented as cal. BP (calendar years Before Present $=1950$ ), and as historical dates ( $\mathrm{yr} \mathrm{BC} / \mathrm{AD}$ ), in order to compare with other geological and archaeological/dendrochronological studies.

\section{Macrofossils}

To assess the potential of the 45 soil samples collected for the analyses of seeds and insects/mites, 15 were scanned for macrofossils after sieving of the soil through a set of sieves, of which the smallest mesh-width was $0.5 \mathrm{~mm}$. The 15 samples produced only a few, corroded, seeds. As conservation conditions for insects and mites are similar to those for botanical macrofossils, the quality of insect and mite remnants would be equally low. Consequently, the analysis of these categories was dropped.

\section{Wood analysis}

From all recorded and described wood remnants, small pieces of about five cubic centimeters were collected for wood identification. Tree species such as oak and ash can be identified with the naked eye, but most species have to be identified with a transmitting light microscope using magnifications of up to 250 times. The wood anatomy was examined in three 
planes: transverse, radial and tangential to the axis of the wood. Thin slices cut with a razor blade from sections along these planes were wetted and placed between two glass slides. No permanent slides were made. For identification, the reference work of Schweingruber (1982) was used. For dendrochronological analysis see methods in Sass-Klaassen \& Hanraets (2006).

\section{Results}

\section{Soil development}

The profile description of the location where the samples for micromorphological and palynological research were taken is presented below (Table 1). In Figure 4 the profile information and sampling locations are given.

Three grain-size analyses were performed by laser diffraction. They are from the following layers: I. ACg, base of the clay layer, $55 \mathrm{~cm}-0 . D$.; II. 5AC, sandy humous material, $90 \mathrm{~cm}-0 . D$. and III. 6E, coversand, $101 \mathrm{~cm}-0$. D. (Fig. 5). The composition of the coversand and the sand in the sandy humous layer $5 \mathrm{AC}$ is almost identical, indicating that the sand present in the sandy humous layer is blown-in coversand. The clay layer on top of the peat is a pure clay, with hardly any fine silt, no coarse silt and no sand fraction. As the laserdiffraction method compared to the pipette-method underestimates the clay fraction < $2 \mu$ m (Buurman et al. 1997; Konert \& Vandenberghe, 1997) probably almost the whole sample will be $<4 \mu \mathrm{m}$ (pers. comm. Buurman).
Three bulk samples for ${ }^{14} \mathrm{C}$ dates were collected from the pollen monolith tins of the following layers: $1.2 \mathrm{AC}$, top of the peat; 2. 3AC, base of the peat and 3. 5AC, base of the sandy humous layer. The depths and results are given in Table 2.

From the data presented the following sequence of events can be distinguished.

In a coversand depression a podzol developed. The groundwater level started to rise and a sandy organically rich layer accumulated at the surface. Based on the dating of the alkaline residue, the formation of this layer was well underway between $1630-1510$ BC (3580 - $2960 \mathrm{cal}$. BP). In this parent material soil formation resulting in an accumulation of humous acid had taken place. The humous acid present in this sediment was dated between 1442 - 1370 BC (3392 - 3320 cal. BP). The formation of the peat on top of this sandy humous material started when the groundwater level reached the surface and ended when the peat became covered with a clay deposit. Peat growth started between 6 - 102 AD (1944 - $1848 \mathrm{cal}$. BP) and ended between 474 - 538 AD (1476 - 1412 cal. BP). During this period the wetland wood existed.

To estimate whether the rise in groundwater level was due to a rise in regional or local water levels the ${ }^{14} \mathrm{C}$ date of the base of the peat was plotted in the mean sea level-curve of Van der Plassche (1982). The result is presented in Figure 6. A detailed explanation of the background and layout of this figure can be found in Makaske et al. (2003). The date fitted well when the curve was extrapolated to the beginning of our era. As the samples could be precisely collected from an excavated profile wall that was accurately leveled and a wetland

Table 1. Profile description.

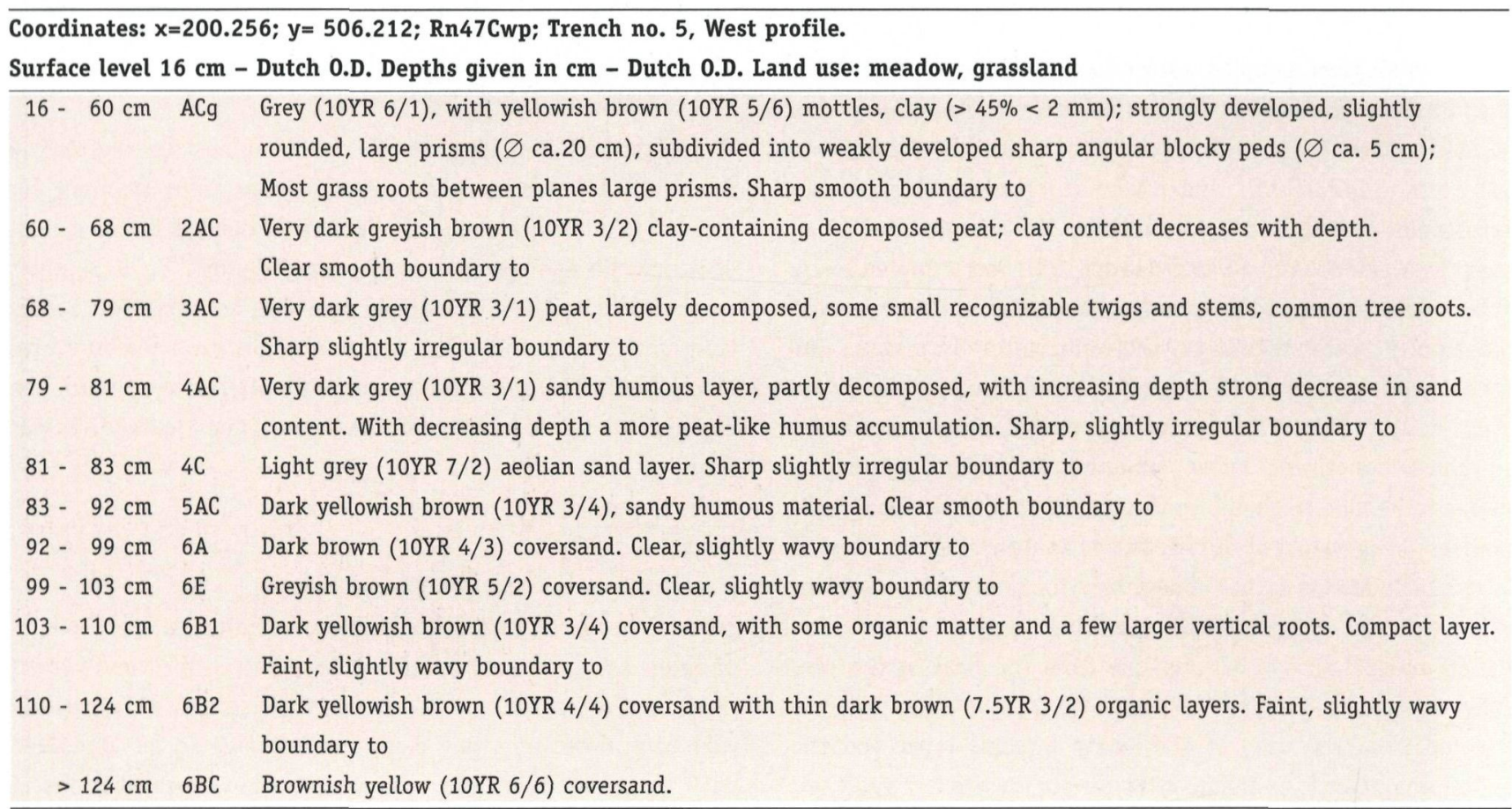




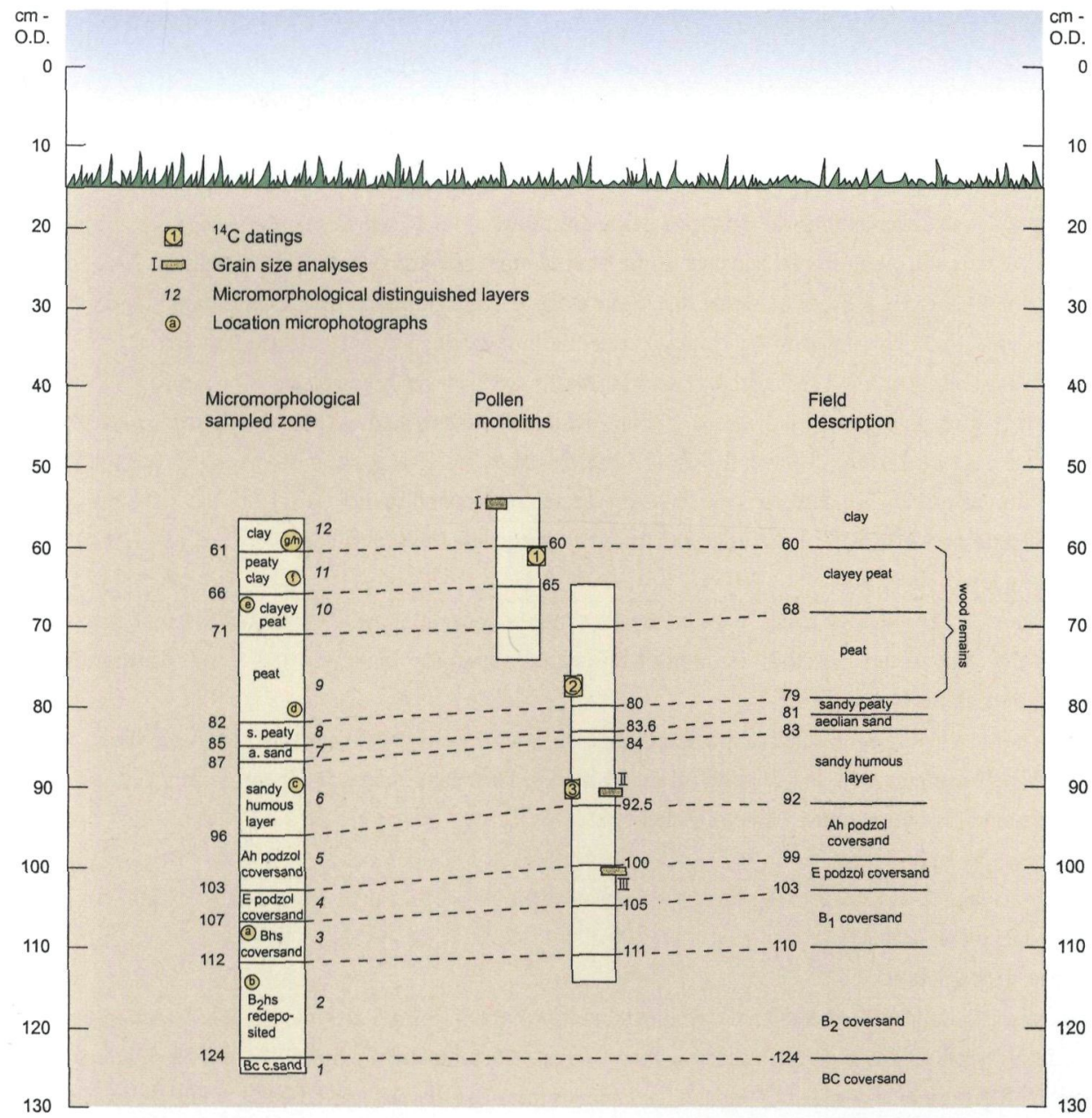

Fig. 4. Profile of sampled excavation trench with location of the micromorphological sampled zone, pollen monoliths and field description, all ca. $50 \mathrm{~cm}$ from each other. In the micromorphologically sampled zone the microscopically distinguished layers and the locations of the microphotographs of Figure 7 are given. In the pollen monolith tins the locations of the ${ }^{14} \mathrm{C}$ and grain size analysis samples are given.

wood growing at surface level the potential error sources in the ${ }^{14} \mathrm{C}$ dates are supposed to be low. Hence the peat growth at Zwolle-Stadshagen can be attributed to a regional rise in groundwater level and is a consequence of the general evolution of mean sea level in the Holocene.

\section{Insight into the past landscape from micromorphology}

Twelve layers could be distinguished in the studied $70 \mathrm{~cm}$ of the profile of which the following interpretation could be made. The micromorphological analyses are given in Table 3. Key features in the reconstruction of the landscape history are illustrated in Figure 7.

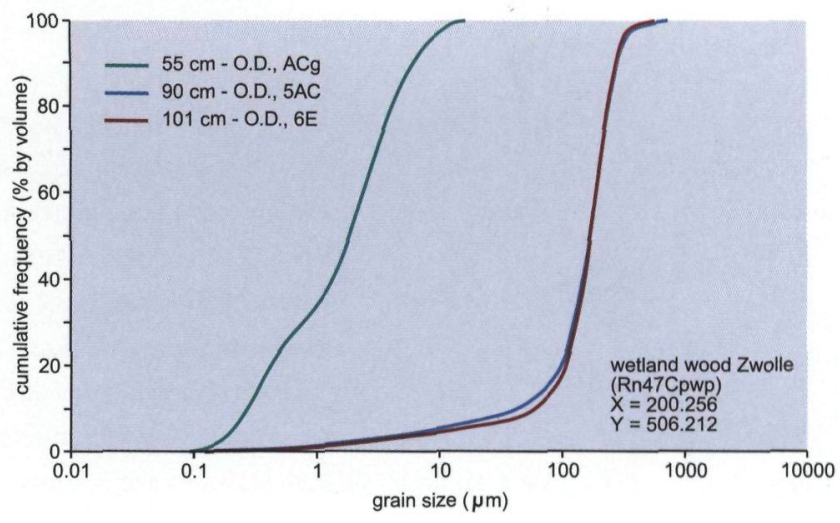

Fig. 5. Grain size analyses of the clay on top of the peat (ACg), the sandy humous layer (5AC) and the E horizon of the coversand podzol (6E).

Table 2. Radiocarbon dates from the studied section.

\begin{tabular}{|c|c|c|c|c|c|c|c|}
\hline $\begin{array}{l}\text { Sample } \\
\text { name }\end{array}$ & Laboratory nr. & $\begin{array}{l}\text { Depth (cm below } \\
\text { Dutch O.D.) }\end{array}$ & Material & $\begin{array}{l}{ }^{14} \mathrm{C} \text {-age } \\
\text { (yr BP) }\end{array}$ & $\begin{array}{l}\text { Median cal. age }{ }^{1} \\
\text { (yr BC/AD) }\end{array}$ & $\begin{array}{l}1 \sigma \text { cal. age range }{ }^{1} \\
(\mathrm{yr} \mathrm{BC} / \mathrm{AD})\end{array}$ & cal. age BP \\
\hline Zwolle I & GrN-27024 & $60.5-62.5$ & peat (bulk) & $1540 \pm 30$ & $503 \mathrm{AD}$ & $474-538 \mathrm{AD}$ & $1476-1412$ \\
\hline Zwolle II & GrN-27025 & $76.5-79.0$ & peat (bulk) & $1950 \pm 40$ & $51 \mathrm{AD}$ & $6-102 \mathrm{AD}$ & $1944-1848$ \\
\hline Zwolle III & KIA-19154 & $89.5-91.5$ & soil (alkali residue) & $3280 \pm 45$ & $1571 \mathrm{BC}$ & $1630-1510 \mathrm{BC}$ & $3580-2960$ \\
\hline Zwolle III & KIA-19154 & $89.5-91.5$ & soil (humic acid) & $3145 \pm 30$ & $1406 \mathrm{BC}$ & $1442-1370 \mathrm{BC}$ & $3392-3320$ \\
\hline
\end{tabular}

1 The Groningen calibration program (version CAL25) was used (Van der Plicht, 1993). The degree of smoothing of the calibration curve was based on Törnquist \& Bierkens (1994): $\sigma_{\mathrm{s}}=200$ was applied. 
Table 3. Micromorphological analyses of the studied section.

\begin{tabular}{|c|c|c|}
\hline Layer 1 & Parent material & - Open packed coversand \\
\hline $124-126 \mathrm{~cm}-0 . D$. & Features & $\begin{array}{l}\text { - Common loosely infilled fossil root channels, locally containing partly decomposed root remnants. } \\
\text { Infilling with parent material; decomposition organic remnants mainly chemical/bacteriological } \\
\text { - Common small accumulations of black framboïdal pyrite in and near decomposed root remnants } \\
\text { - Thin continuous humus-iron coatings up to } 5 \mu \mathrm{m} \text { around coversand grains }\end{array}$ \\
\hline \multirow[t]{2}{*}{$\begin{array}{l}\text { Layer } 2 \\
112-124 \mathrm{~cm}-0 . D \text {. }\end{array}$} & Parent material & $\begin{array}{l}\text { - Laminated, weakly sorted, by water and wind redeposited coversand, with thin organic layers, } \\
2 \text { - } 3 \mathrm{~mm} \text { thick, composed of horizontally oriented non-woody, organic debris (Fig. 7b) }\end{array}$ \\
\hline & Features & $\begin{array}{l}\text { - Common loosely infilled fossil root channels, locally with partly decomposed root remnants } \\
\text { Infilling with parent material; decomposition organic remnants mainly by consumption by soil fauna } \\
\text { - Common accumulations of black framboïdal pyrite mainly in and near the decomposed root remnants } \\
\text { - Continuous humus-iron coatings up to } 30 \mu \mathrm{m} \text { around coversand grains } \\
\text { - Coversand in the infill of fossil root channels regularly devoid of coatings }\end{array}$ \\
\hline Layer 3 & Parent material & - Open packed coversand \\
\hline
\end{tabular}

$107-112 \mathrm{~cm}-$ O.D. Features - Common loosely infilled fossil root channels, regularly containing partly decomposed root remnants. Infilling with parent material; decomposition organic remnants mainly by soil fauna. Root remnants include tree roots.

- Common accumulations of black framboïdal pyrite in and near the decomposed root remnants

- Continuous humus-iron coatings up to $40 \mu \mathrm{m}$ around coversand grains (Fig. 7a), locally filling the packing voids between the mineral grains

Layer 4

Parent material - Open packed coversand

$103-107 \mathrm{~cm}-0 . D$. Features - Same as layer 3, except for the humus-iron coatings, which occur only locally as very thin, discontinuous coatings

Layer 5

Parent material - Open packed coversand

$96-103 \mathrm{~cm}-$ - O.D. Features - Common loosely infilled fossil root channels, regularly containing partly decomposed root remnants. Infilling with parent material; decomposition organic remnants mainly by soil fauna. They include tree roots. A few more or less intact organic remnants of moss-like tissues and sclerotia. Local accumulations of more or less shapeless, black amorphous organic material. Organic material ca. $30 \%$ vol

- Common accumulations of black framboïdal pyrite in and near the decomposed root remnants and amorphous organic matter

Layer 6

$87-96 \mathrm{~cm}-0 . D$.

Parent material - Accumulating humous to peaty soil material with aeolian coversand blown in at random (Fig. 7c). Ratio humous material, blown-in sand ca. $50: 50 \% \mathrm{v} / \mathrm{v}$

Features - The humous to peaty soil material is strongly decomposed by soil (meso)fauna and chemical/ bacterial processes. Common root channels, regularly containing partly decomposed root remnants. They include some, less decomposed, tree roots. A few more or less intact organic remnants of moss-like tissues, buds and sclerotia

- Common accumulations of black framboïdal pyrite in and near the peaty soil material

- Locally a few gypsum rosettes in and near the peaty soil material. $\varnothing$ rosettes around $190 \mu \mathrm{m}$

Layer 7

$85-87 \mathrm{~cm}-0 . D$

Layer 8

$82-85 \mathrm{~cm}-0 . D$
Parent material - Pure blown-in aeolian coversand

Features - A few loosely infilled fossil root channels, regularly containing partly decomposed root remnants. Infilling with parent material; decomposition few organic remnants mainly by soil (meso)fauna

- A few accumulations of black framboïdal pyrite in and near the organic remnants

Parent material - Peaty soil material with aeolian coversand blown in at random. The peaty material increases upward from 40 to $70 \% \mathrm{v} / \mathrm{v}$ and shows a horizontal lamination

Features - The peaty soil material largely consists of amorphous organic matter and recognizable epidermal tissues of roots and stems. The interior tissues are often missing and the complete epidermal tissues flattened and horizontally oriented by pressure exerted from the top, accentuating a horizontal lamination. Also layers with mossy material. Common communition of mesofauna. Few fungal hyphen and fungal blackening of organic material.

- A few large remnants of tree roots, one of oak

- Common at random sclerotia

- A few small accumulations of black framboïdal pyrite in and near organic material 
Layer 9

$71-82 \mathrm{~cm}-0 . D$.
Parent material - 100\% dark brown organic material, peat (Fig. 7 d)

Features - The peat is composed of ca. $60 \%$ unrecognizable organic matter in which horizontal layers with epidermis tissues of ferns of the Dryopteris type occur (det. by D. van Smeerdijk and P. Cleveringa) and mossy material. Most unrecognizable organic matter became amorphous by chemical/bacterial processes

- Common large remains of tree roots, most in the middle zone between $74-79 \mathrm{~cm}-0$. D., $\varnothing$ up to $1.5 \mathrm{~cm}$

- Common small irregular faunal voids due to communition in the peat and root remnants. Locally small accumulations of organic faecal pellets, including those of Enchytraeïdae

- In the top a few worm channels infilled with shapeless organo-mineral material composed of organic matter $(>50 \% \mathrm{v} / \mathrm{v})$ and clay $(<2 \mu \mathrm{m}), \varnothing \mathrm{ca} .4 \mathrm{~mm}$

\section{Layer 10}

$66-71 \mathrm{~cm}-0 . D$.

Layer 11

$61-66 \mathrm{~cm}-$ O.D.
Parent material - Dark brown organic material, peat, with about $20 \%$ non-calcareous pure clay, $<2 \mu \mathrm{m}$, with a very few silt particles up to $4 \mu \mathrm{m}$

\section{Features $\quad-$ Same composition peat as in layer 9}

- Few remains of tree roots

- Common worm channels infilled with shapeless organo-mineral material composed of organic matter $(>50 \%)$ and pure clay $(<2 \mu \mathrm{m}), \varnothing \mathrm{ca} .4 \mathrm{~mm}$ (Fig. $7 \mathrm{f}$ ). About $50 \%$ of the layer bioturbated

- Common small irregular faunal voids due to communition in the peat and root remains. Locally small accumulations of organic faecal pellets, including those of Enchytraeidae (Fig. 7e) and perhaps some mites. Peat area affected: about $20 \%$

Parent material - Humous pure non-calcareous clay, $<2 \mu \mathrm{m}$, very few silt particles up to $4 \mathrm{~mm}$. Weak horizontal lamination accentuated by differences in humus content. Clay content between $75-90 \% \mathrm{v} / \mathrm{v}$. Few elongated organic tissues horizontally oriented and embedded in clay laminae

Features - Common worm channels infilled with shapeless organo-mineral material composed of organic matter $(>50 \%)$ and clay $(<2 \mu \mathrm{m}), \varnothing$ ca. $4 \mathrm{~mm}$. About $40 \%$ of the layer bioturbated

- Common small irregular faunal voids due to communition in the organic matter in the worm channels. Locally small accumulations of faecal pellets, including those of Enchytraeidae and perhaps some mites. Worm area affected: about $40 \%$

Layer 12

Parent material $-100 \%$ pure non-calcareous clay, $<2 \mu \mathrm{m}$, with a very few silt particles up to $4 \mathrm{~mm}$, with a horizontal lamination. A very few small elongated organic tissues horizontally oriented and embedded in clay laminae (Fig. $7 \mathrm{~g} / \mathrm{h}$ ) in the first centimeter

Features - At the base in the first centimeter a very few worm channels infilled with shapeless organo-mineral material composed of organic matter and clay $(<2 \mu \mathrm{m}), \varnothing$ ca. $4 \mathrm{~mm}$. Organic material in excreta affected by communition of mesofauna

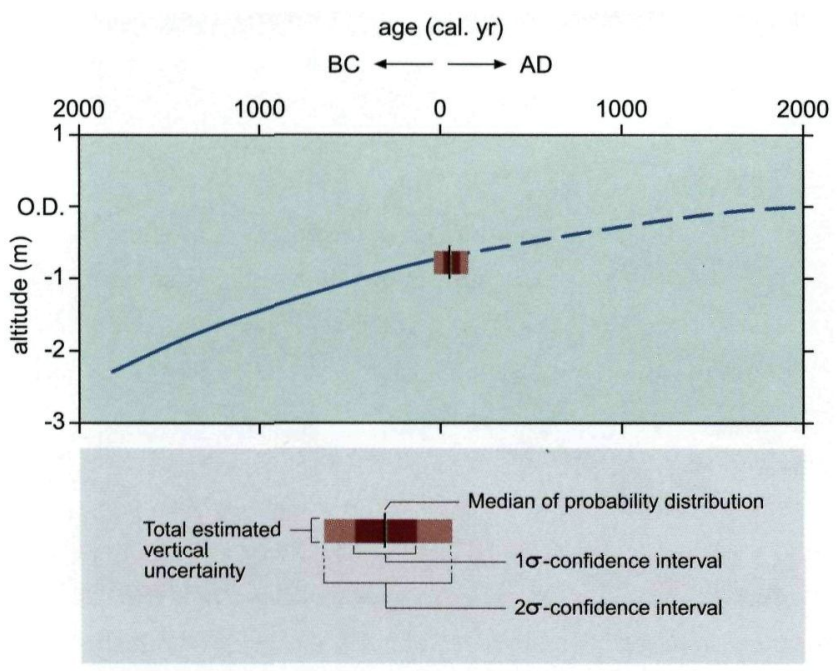

Fig. $6 .{ }^{14} \mathrm{C}$ dating basal peat wetland wood Zwolle-Stadshagen plotted on the mean sea-level curve after Van der Plassche (1982).
- Layer 1 (124 - $126 \mathrm{~cm}$ - 0.D.) is a BC horizon of a truncated podzol, developed in aeolian coversand.

- Layer 2 (112 - $124 \mathrm{~cm}$ - 0.D.), in the field resembling a Bh horizon of a podzol with thin bands of organic matter accumulation in the subsoil, is a sedimentary layer of coversand redeposited by wind and water and includes thin layers of organic debris deposited by water (see Fig. 7b).

- Layer 3, 4, 5 (96 - $112 \mathrm{~cm}$ - 0.D.) form one aeolian coversand deposit.

- In layers 2, 3, 4, 5 (96 - $124 \mathrm{~cm}$ - 0.D.) a podzol had developed with humous mineral topsoil (Ah, layer 5: $96-103 \mathrm{~cm}-0 . D$.), a bleached, eluvial layer ( $E$, layer 4: $103-107 \mathrm{~cm}-0 . D$.) and accumulation layers of organic matter in combination with iron and aluminum forming amorphous coatings around sand grains (B1hs, layer 3: 107 - $112 \mathrm{~cm}$ - 0.D., Fig. 7a; B2hs, layer 2: $112-124 \mathrm{~cm}-0 . D$.). This type of coating is formed in well-drained podzols developed on poor parent materials. 

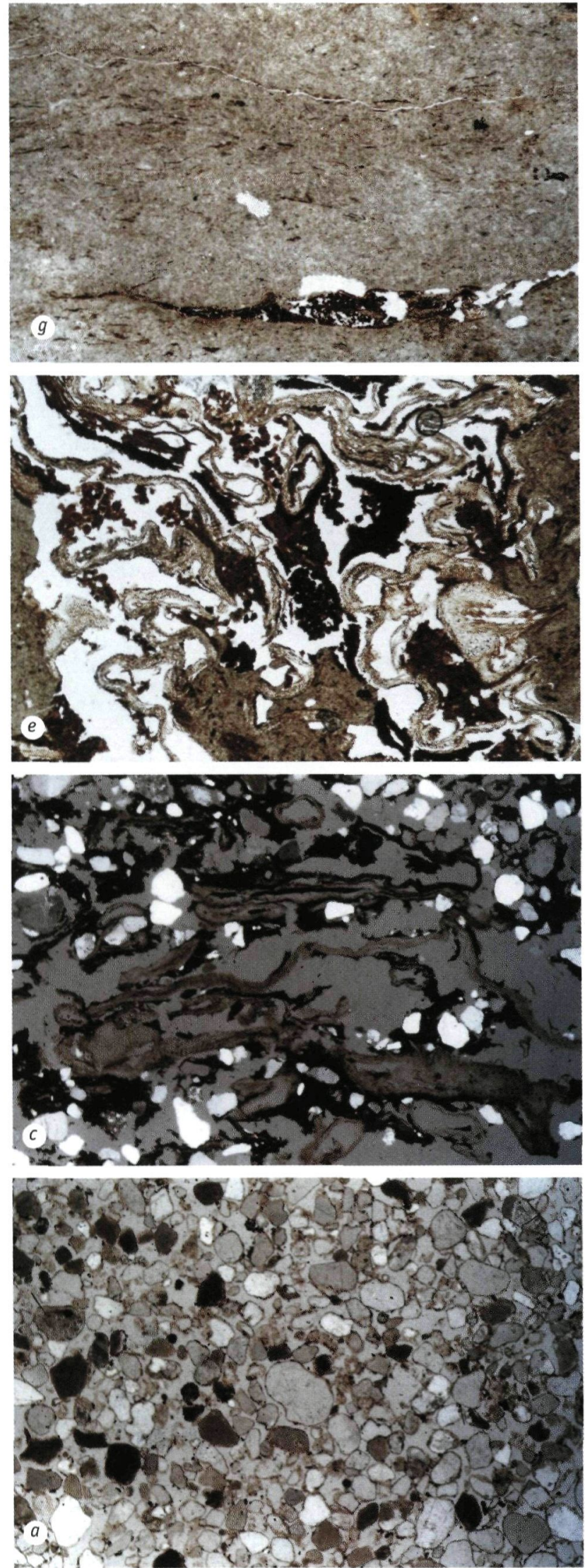


Fig. 7. Microphotographs of key features for the reconstruction of the landscape history. The location of these features is given in figure 2, first column. Magnifications all $\times$ 25. a. B1hs, amorphous coatings around coversand grains; b. geogenetic organic debris in B2hs; c. sandy humous layer with compressed epidermal tissues; $d$. peat with remnants of Dryopteris ferns.; e. decomposition peat by enchytraeids; $f$. decomposition peat by worms; $g$. base pure clay deposit with some synsedimentary deposited organic material, plain light; $h$. as $g$, with crossed polarizers. 
In this well-drained podzol the groundwater level started to rise. Under fluctuating but steadily rising groundwater levels pyrite was formed in and near organic materials present in the podzol and the organic debris in layer 2. In the podzol Ah horizon, besides moder humus (largely consisting of excrements of mesofauna) also mor humus occurred as result of poorer (wetter) conditions for decomposition. The few moss-like tissues and sclerotia may indicate a change to a wet heather-like vegetation.

- Layers 6, 7, 8 (82 - $96 \mathrm{~cm}$ - 0.D.), the sandy, humous layers, are the result of increasingly wet conditions, resulting in the accumulation of more or less decomposed organic matter. The presence of a few gypsum rosettes in layer 6 indicates local mesotrophic, non acidic conditions. This is supported by the presence of moder humus characteristic of a slightly acid $\mathrm{pH}$. Towards the top (layer 8 ) the organic material becomes more peaty. Based on the detected remains of organic matter, a kind of moorland is possible. The organic material is strongly horizontally compressed. Remarkable is the continuous randomly input of blown-in coversand (Fig. 7c) from nearby sources in layers 6 and 8 and a pure sand layer about $2 \mathrm{~cm}$ thick (layer 7). This pattern of blown-in sand generally can only be the result of sand catching in a low more or less closed, herbaceous vegetation, with a low quantity of trees. Trees catch more sand in the prevailing wind direction, resulting in an uneven distribution of sand.

- Layer 9 (71 - $82 \mathrm{~cm}$ - 0.D.) is a partly decomposed peat layer, with remnants of ferns of the Dryopteris type (fig. 7d) formed after the groundwater level reached the surface. Trees grew on the peat, as tree roots are common. The presence of remnants of ferns of the Dryopteris type generally coincide with the occurrence of Alnus trees in these kinds of deposits as they are rather resistant to decomposition in that environment (pers. comm. P. Cleveringa). The $\mathrm{pH}$ became more acidic as mesofauna was limited and bacterial decomposition common. Here too, organic material is strongly horizontally compressed.

- Layer 10 (66 - $71 \mathrm{~cm}$ - 0.D.) is also a woodland peat, but one that is periodically flooded whereby thin layers of pure clay were deposited. In between, drier conditions prevailed, as many traces of terrestrial worms and mesofauna, especially enchytraeids (Fig. 7e) were found. For their presence the $\mathrm{pH}$ had to increase to slightly acidic or neutral. Some wormcasts were present in the top of the lower peat layer, indicative of fluctuating groundwater levels also in this zone. The peaty material was compressed.

- Layer 11 (61 - $66 \mathrm{~cm}$ - 0.D.) is a partly bioturbated humous clay of the same type as in layer 10 on which trees have grown. Prolonged periods with pure clay deposition from flooding alternated with longer drier periods in which organic matter accumulated and worms mixed clay and organic matter by ingestion (Fig. 7f). As the parent material contained less organic matter, mesofauna re-ingested about half of the recognizable organic matter in worm excreta. Some, most probably local, synsedimentary deposited organic material is present at the base of the clay layer.

- Layer 12 (57-61 cm - 0.D.), composed of nearly 100\% pure clay, is a horizontally laminated subaqueous deposit (Fig. 7 $\mathrm{g} / \mathrm{h}$ ). As synsedimentary deposited organic matter is almost absent after a few centimetres depth and faunal influence stopped, the woodland on the peat must have been inundated for prolonged periods.

From the data presented above the following hydrological sequence of events can be reconstructed.

In the sandy humous layer on top of the drowned podzol features occurred indicative for different local conditions. The gypsum rosettes are indicative for local mesotrophic, non acidic conditions, the moder humus occurring is characteristic for a slightly acid $\mathrm{pH}$, and the peaty material no more decomposed by mesofauna represents acidic conditions. They are related to different water qualities from several sources. The gypsum rosettes point to a freshwater stream, the moder humus to mainly rainwater and the no more decomposed peaty material by mesofauna to a dominance of groundwater. In this period before the start of the peat growth proper, presence of small streams and local depressions filled with mixtures of rain and groundwater water seems obvious.

The lower part of the peat layer is a typical lowland peat covered with trees, formed when the groundwater reached the surface. The conditions were acidic as decomposition by mesofauna was limited and that of bacteria common. In the upper part of the peat hydrological conditions changed. A new stream periodically flooded the woodland peat, changing the water quality from acidic to almost neutral, depositing thin layers of almost $100 \%$ pure clay. In between the times the woodland peat was periodically flooded, drier conditions prevailed as many traces of terrestrial worms and mesofauna, especially enchytraeids, were found.

The pure clay encountered cannot be marine as marine clays are deposited in mud flakes containing a substantial silt fraction with a rather constant ratio $<2 \mu \mathrm{m} /<16 \mu \mathrm{m}$ (Zuur, 1954; Wiggers, 1955). Moreover terrestrial worms were active in this layer, that cannot survive in saltwater. Consequently these clays are freshwater deposits. The findings of Kuijer \& Rosing (1994), who place the boundary of marine and fluvial deposits just north of the excavated woodland, is correct. Secondly, the deposition of marine sediments took place from the 14th century onwards and this clay sedimentation started much earlier, about half way during the peat growth between AD $200-400$ (ca. 1750 - 1550 cal. BP).

Prolonged periods with clay deposition from flooding alternated with longer drier periods in which organic matter accumulated and worms mixed clay and organic matter by ingestion. In the end the peat became covered with a clay deposit of about $40-60 \mathrm{~cm}$ thick composed of almost $100 \%$ 
clay $<2 \mu \mathrm{m}$. The woodland must have been inundated completely and as the input of organic material from e.g. leaves and faunal activity stopped, the woodland would have drowned. This clay deposit did not belong to the floodplain deposits of the river IJssel. Deposits of the same soil type (Rn47C), but situated about $15 \mathrm{~km}$ upstream, were composed of clay contents up to $50 \%$, fine silt fractions $(2-16 \mu \mathrm{m}$ ) varied between $20-30 \%$ and the coarse silt fraction $(16-50 \mu \mathrm{m})$ between $15-25 \%$ (Stiboka, 1966; Fig. 8). Moreover the meander belt along the IJssel was formed after the start of reclamation activities around AD 1100 (ca. 850 cal. BP) (Kuijer \& Rosing, 1994), at least 500 years later. The clay deposit covering the woodland peat was composed of almost $100 \%$ clay $<2 \mu \mathrm{m}$ and therefore mostly resembled a lacustrine deposit (Reineck \& Singh, 1973). The most logical interpretation of the sedimentary environment would to be a temporary lake drowning the woodland.

The composition of the clay, almost only $<2 \mu \mathrm{m} \varnothing$, may be the result of a filtering of sediment by a closed herbaceous vegetation. During the temporary inundations when peat growth continued this could have been the case. To preserve such a vegetation for prolonged periods when inundated during the sedimentation of a clay deposit of about $40-60 \mathrm{~cm}$, without

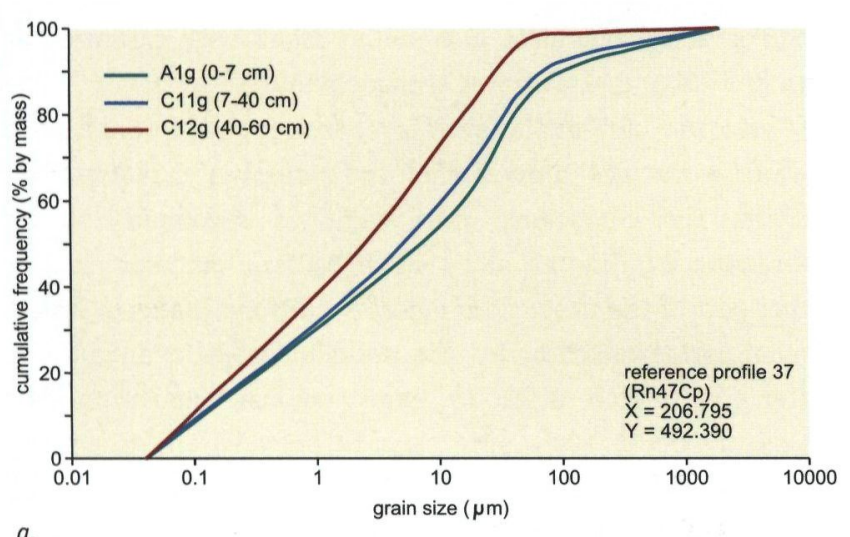

$a$.

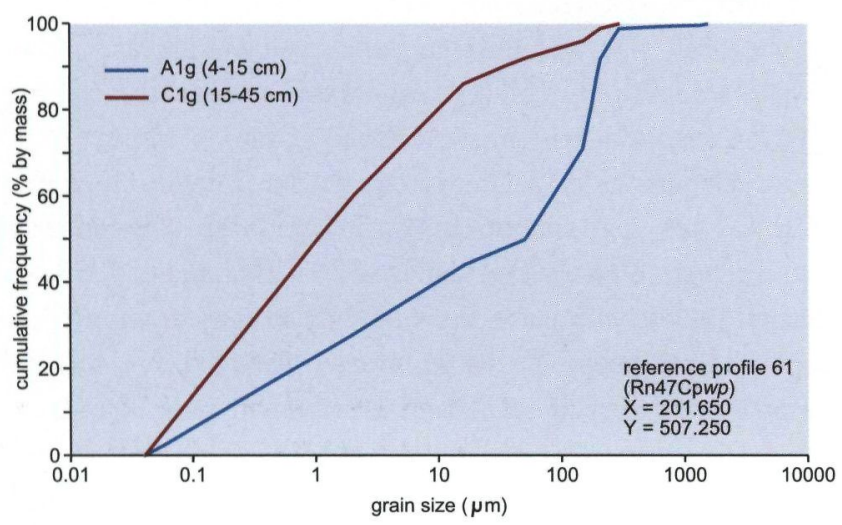

$b$.

Fig. 8. Grain size analyses from reference profiles of the same soil unit in the study area from the soil map of the Netherlands $1: 50,000$. a. $14 \mathrm{~km}$ south of the excavation in the IJssel meander belt; $b .2 \mathrm{~km}$ northeast of the excavation near the Zwarte Water. synsedimentary deposited organic material in a drowned woodland is not a real option. The strong horizontal compression of organic materials occurring in the sandy humous layer and the peat deposits also points to a continuously exerted pressure by a heavy load of water and not to temporary inundations.

\section{Insight into the past vegetation from palynology}

\section{The pollen diagram}

The palynological research focussed on eight pollen samples for detailed analysis selected from an assessment of 20 subsamples. The results of the palynological analyses are presented in Figure 9. The difference between regional and local woodland species is based on the wood analyses performed, which is discussed in the next section. Not categorised were the Cyperaceae (Sedge family) and the Poaceae (Grass family). Because of their large ecological range, they should be classified among the 'miscellaneous' group, but certain members of these families are of such importance to a vegetation reconstruction that they have been placed between the local woodland species and the bog/heathland species.

\section{Sandy humous layer: $84 \mathrm{~cm}-0$.D.}

At this level the AP amounts to $70 \%$. Among the tree pollen alder (Alnus) is the most common, followed by oak (Quercus). The pollen of ash (Fraxinus excelsior), birch (Betula), hazel (Corylus avellana) and willow (Salix) is present in low percentages. Notable among the Non-Arboreal Pollen and spores are ericaceous plants (including heather, Calluna), the sedge family (Cyperaceae) and grasses (Poaceae), Filipendula and the ferns Dryopteris or Thelypteris.

An open to semi-open woodland can be assumed, growing in the depression on a moist, partly mineral and partly organic substrate. The algae, e.g. Botryococcus, Closterium, Zygnemataceae and types $128 \mathrm{~A}$ and B (as classified by Van Geel, 1978, Pals et al., 1980, Van Geel et al., 1981, 1989), however, show that open water occurred as well. Probably it was shallow water, in which also species such as yellow iris (Iris pseudacorus), branched bur-reed (Sparganium erectum) and greater water parsnip (Sium latifolium) occurred. The percentages of the ericaceous plants, including heather (Calluna), are relatively low. Since experimental research has shown that most ericaceous and bog species (including Calluna) disperse their pollen only a few metres (e.g. Janssen, 1984; Evans \& Moore, 1985; Bradshaw, 1991), it is assumed that these plants also formed a (small) part of the vegetation occurring on higher locations in the depression.

No evidence of cereals has been found. Yet traces of human presence were present in the form of so-called anthropogenic indicators (see e.g. Behre, 1981), such as mugwort (Artemisia), greater plantain (Plantago major) and corn spurrey (Spergula arvensis). 


\section{Zwolle Stadshagen}
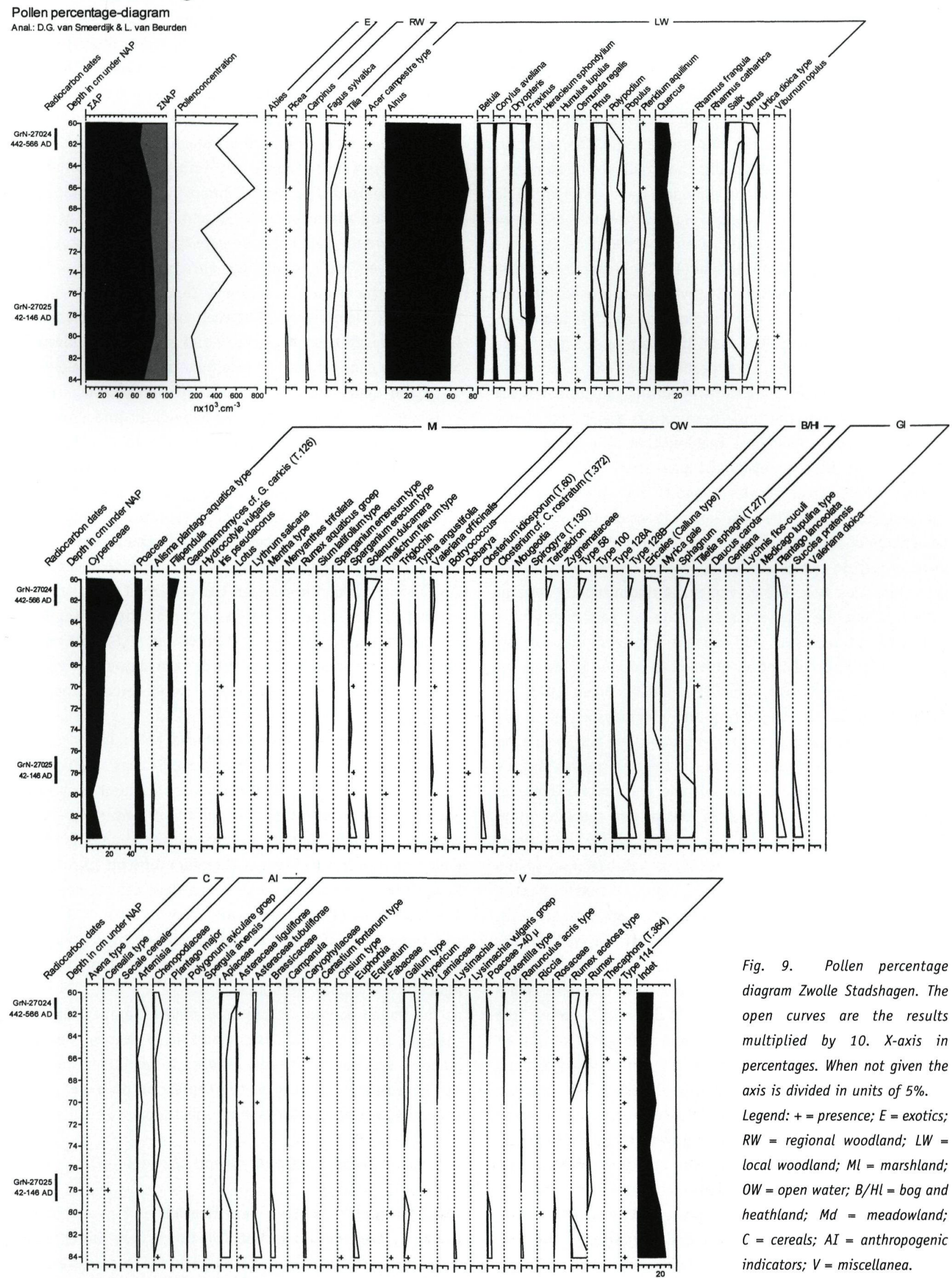

Fig. 9. Pollen percentage diagram Zwolle Stadshagen. The open curves are the results multiplied by $10 . \quad X$-axis in percentages. When not given the axis is divided in units of $5 \%$. Legend: $+=$ presence; $E=$ exotics; $R W=$ regional woodland; $L W=$ local woodland; $M l=$ marshland; $\mathrm{OW}=$ open water $\mathrm{B} / \mathrm{Hl}=$ bog and heathland; $M d=$ meadowland; $C=$ cereals; $A I=$ anthropogenic indicators; $V=$ miscellanea. 
Peat layer: $80-62 \mathrm{~cm}-0 . D$.

On top of the sandy humous layer peat was formed, which had decomposed and compressed to a thickness of approximately $20 \mathrm{~cm}$ (see Fig. 4). The palynological analyses of the peat showed two overall indicative features, viz. marked changes in the 'unidentified pollen' curve and in the pollen concentration at the depths of 70 and $62 \mathrm{~cm}-0 . D$, respectively. The 'unidentified pollen' curve represents grains that could not be identified because of poor preservation. An increase of unidentifiable pollen might indicate that the organic material had been decomposing, which happens when the water table drops below the surface for a longer time. Low pollen-concentration can be due to several factors. However, when peat layers with low pollen concentration appear to coincide with high proportions of unidentifiable pollen, indicative for peat decomposition, it has to be concluded that peat growth was periodically interrupted; notably, about half-way during the growth of the peat layer and near the top. These results are in accordance with the micromorphological analyses that also showed that the growth of the peat repeatedly stagnated.

The palynological results suggest that the vegetation changed little during the period of peat accumulation. The AP percentage is on average $80 \%$, suggesting that the trees grew in semi-open to closed woodland. Pollen of alder, oak and ash is the most common. The palynological findings point towards alder carr, but the alder percentages are not particularly high and herbs of reedland and marshes appeared only in low percentages. Stortelder et al. (1999) has defined today's alder carr (Alnetea glutinosae Braun-Blanquet et Tüxen 1943) for the Netherlands. This vegetation type nowadays occurs in wet places on peat, which in winter are inundated and in summer dry out only superficially. The dominant tree species is black alder. A characteristic feature of alder carr is a microrelief with open water where plants of marsh- and reedland grow. Around the higher places in this microrelief, viz. old (alder) stumps, there may be elements of an oak-beech woodland (Quercetea robori-petraeae Braun-Blanquet et Tüxen 1943), a type of forest that prefers somewhat drier, oligotrophic soils. Woodland herbs rarely occur in alder carr. Instead, sedges occupy a prominent place.

Evidence about the growing conditions of the trees comes from the various fern species. From $74 \mathrm{~cm}-0 . D$. upwards, the spores of royal fern (Osmunda regalis) form a continuous curve. This fern species belongs in a moist to wet woodland environment. The curves of oakfern (Polypodium) and bracken (Pteridium aquilinum) show an increase in spore percentages in dry periods with stagnant peat growth and a reduction in wet periods. The values of the sedge family (Cyperaceae) are low at the base of the peat and strongly increase towards the top. Grass species (Poaceae) are represented by low numbers of pollen grains, though at the base and at the top of the peat their values are somewhat higher. Evidence for bog or heathland is virtually absent. Representatives of both marshland and open-water plants are scarse. Evidence relating to the upland vegetation and hence human presence is equally sparse. At the base of the peat layer, at $78 \mathrm{~cm}-0 . D$., some pollen of cereals occurred. At the same level pollen of knotgrass (Polygonum aviculare) was found, and at a depth of $80 \mathrm{~cm}-0 . D$. corn spurrey (Spergula arvensis). Together with ribwort plantain (Plantago lanceolata), a plant of grazed grassland, these are indications of human presence in the vicinity during the period when peat formation started. Apart from ribwort plantain, anthropogenic indicators are absent between 78 and $66 \mathrm{~cm}-0 . D$. At $66 \mathrm{~cm}$ - 0.D., where the peat becomes more clayey near the top, some pollen of rye (Secale cereale) was encountered, but for a windpollinator the amount is very low. This suggests that at that time people were present, but their impact on the landscape in the depression was neglectable and probably they lived and farmed at a considerable distance from the low-lying alder-carr.

In the upper zone of the peat, where the clay content increased (61 - $66 \mathrm{~cm}-0 . \mathrm{D}$.), two apparently antagonistic soil processes were identified in the micromorphological study. The water table dropped below the surface for longer periods, with the result that part of the peat was converted by terrestrial worms and Enchytraeidae (potworms). In between the depression must have been repeatedly inundated, whereby thin layers of clay, invisible to the naked eye, were deposited. The drying-out of the peat on the one hand and the waterlogging on the other hand in all probability affected the composition of the palynomorphs at $62 \mathrm{~cm}-0 . D$., part of them having decomposed. Moreover it will have allowed pollen to be deposited both from the air and by water through the inundations.

In this zone the proportion of arboreal pollen (AP) decreases, while those of the sedge family expand. Besides a reduction of alder pollen, there is a slight increase in willow. Part of the pollen, however, including that of willow and sedge family, could have been washed in through the inundations. The pollen picture in this layer is therefore difficult to interpret. Nevertheless, the pollen suggests that tree density decreased. The percentage of tree pollen (AP) drops to around 70 percent and there is an increase in the species of open water and marshland. Only the presence of ribwort plantain is a faint indication of human influence.

The pollen content at the basis of the clay deposit above the peat at $60 \mathrm{~cm}-0 . D$. is comparable to that of the sandy humous layer below the peat. An open to semi-open woodland can be assumed, growing in the depression on a wet, partly mineral (clay) and partly organic substrate.

\section{Vegetation reconstruction by wood analysis}

\section{Wood remnants - species identification}

In total, over 600 fragments of wood were investigated, including 167 from the two test trenches. The preservation of the wood was mediocre, although the wood from the test 
Table 4. Percentages of identified wood species per trench.

\begin{tabular}{lccccccl}
\hline Trenches & $\mathbf{1}$ \& 2 & $\mathbf{3}$ & $\mathbf{4}$ & $\mathbf{5}$ & $\mathbf{6}$ & Total & \\
Total number of samples & $\mathbf{1 3 9}$ & $\mathbf{7 0}$ & $\mathbf{8 6}$ & $\mathbf{1 0 9}$ & $\mathbf{1 1 6}$ & $\mathbf{5 2 0}$ & \\
\hline Ash & 36.7 & 45.7 & 47.7 & 43.1 & 35.3 & 40.8 & Fraxinus excelsior \\
Alder & 23.7 & 21.4 & 31.4 & 33.9 & 47.4 & 32.1 & Alnus \\
Oak & 34.5 & 24.3 & 11.6 & 14.7 & 8.6 & 19.4 & Quercus \\
Willow & 4.3 & 4.3 & 5.8 & 3.7 & 4.3 & 4.4 & Salix \\
Elm & -.7 & - & 2.3 & 1.8 & 1.7 & 1.3 & Ulmus \\
Maple & - & 4.3 & - & - & 0.0 & 0.6 & Acer \\
Alder/Birch & - & - & 1.2 & - & 1.7 & 0.6 & Alnus/Betula \\
Birch & - & - & - & 1.8 & - & 0.4 & Betula \\
cf. Hazel & - & - & - & 0.9 & - & 0.2 & cf. Corylus avellana \\
Purging Buckthorn & - & - & - & - & 0.9 & 0.2 & Rhamnus cathartica \\
\hline
\end{tabular}

trenches was somewhat better preserved. As a result of its indifferent conservation, morphological features such as the shapes of root systems, the height of trees and the presence of branches could not always be ascertained. Even so, valuable evidence was gained from the investigated wood. The results are presented in Table 4 and Figure 10.

The species of 520 wood fragments could be identified. The most common ones were ash (Fraxinus excelsior), alder (Alnus) and oak (Quercus) with 42, 32 and 19 percent of the specimens respectively. The other seven percent were made up of willow (Salix), elm (Ulmus), maple (Acer), birch/alder (Betula/Alnus), birch (Betula), cf. hazel (Corylus avellana) and purging buckthorn (Rhamnus cathartica). The ratio between the three most common species was more or less constant. Only in trench 6 more alder than ash was found (see Table 4). Figure 11 shows the spatial distribution of ash, alder and oak. The various species were fairly evenly distributed across the excavated site; hence only trench five is presented in Figure 11.

The predominance of ash and the presence of elm, maple and purging buckthorn does not point to an alder carr. The species composition, which includes alder, willow, oak and hazel, is indicative for an Alno-Padion Knapp 1942. This woodland type, described for the Netherlands by Stortelder et al. (1999) nowadays occurs on fairly eutrophic soils with a high turnover rate of organic material. Yet at ZwolleStadshagen we are dealing with a woodland on peat in which the organic matter is accumulated instead of recycled.

The wood was preserved in a rather thin peat deposit. Therefore no stratigraphical order, with the moisture-sensitive species such as ash and oak growing in the somewhat higher and drier places, could be identified. It is likely, that the clay which was deposited on the peat, compressed the latter to such an extent that any stratigraphic distinction in terms of the three key species was lost.

\section{Tree characteristics}

Of most trees only parts have been preserved. The heights of ash, alder and oak trees were estimated on the basis of the
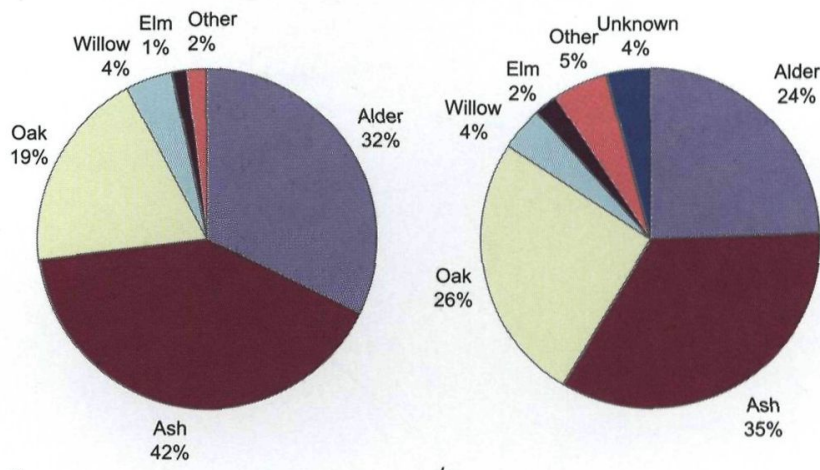

a.

Fig. 10. Pie diagrams representing numbers of wood remnants (a) and reconstructed trees (b).

remaining trunk length in relation to the trunk diameter. In the case of ash $82 \%$ of the recorded trunk lengths $(\mathrm{N}=28)$ was between 2 and $6 \mathrm{~m}$; the two longest trunks were $8 \mathrm{~m}$ long. The range of trunk lengths was wider for oak, with $53 \%$ of the trunks between 4 and $7 \mathrm{~m}(\mathrm{~N}=34)$. Seven trunks exceeded $7 \mathrm{~m}$ with an outlier at $14.8 \mathrm{~m}$. The wood of alder tended to be more fragmented; only twelve trunks could be measured, of which five were between 2 and $5 \mathrm{~m}$ long. The longest was $6.5 \mathrm{~m}$. Although fairly long trunks were recovered, their diameters were on the whole remarkably small. Over $82 \%$ of the ash trunks had a diameter between 5 and $25 \mathrm{~cm}(\mathrm{~N}=23)$. In the case of oak $79 \%$ of the stems were between 10 and $30 \mathrm{~cm}$ thick $(\mathrm{N}=24)$. The diameter of the measurable alder trunks varied between 10 and $18 \mathrm{~cm}$.

Dendrochronological investigation showed that the average age of the analysed ashes was 133 years with a maximum of 245 years. That of oak was 165 years with a maximum of 343 years (Sass-Klaassen \& Hanraets, 2006). Hence it may be assumed that the recorded tree lengths and diameters were those of mature trees.

Ash and oak trees can reach a maximum height of $35 \mathrm{~m}$. Given their relatively small trunk diameters, the trees at Zwolle-Stadshagen did not attain such heights. If we assume that the crowns of both species were as high as the lengths of 


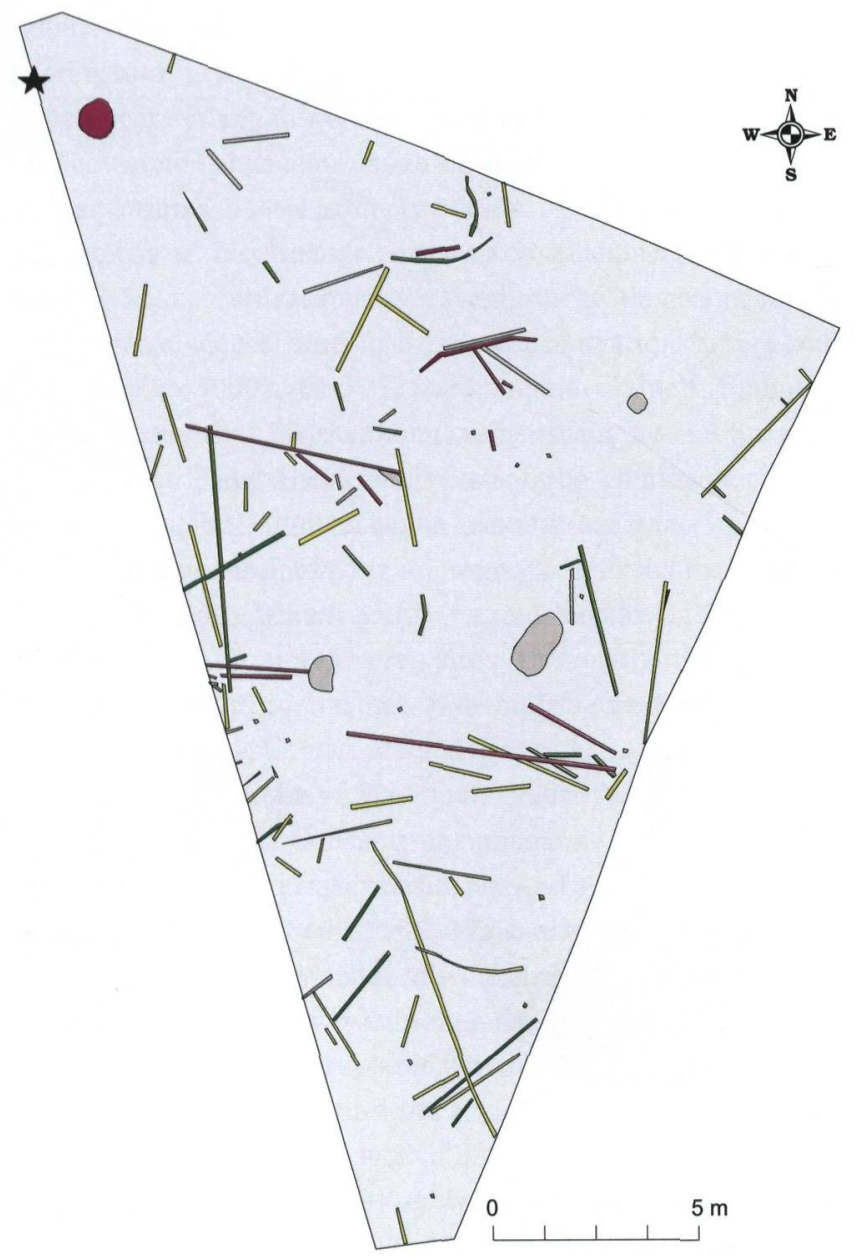

Fig. 11. Distribution of wood remnants of ash (yellow), alder (green) and oak (purple) in trench 5. Tree falls grey (3). The location of the combined sampling for micromorphological and palynological studies is marked by an asterisk.

the recovered trunks, then ash trees will on average have reached 4 to $12 \mathrm{~m}$ with exceptions of $16 \mathrm{~m}$. The oaks will generally have grown to 8 to $14 \mathrm{~m}$ with an exception of $30 \mathrm{~m}$ height. Since the alder wood has been poorly preserved, it was not possible to reconstruct the average heights of trees. Judging by present-day trees on wet soils, they will have been not taller than 10 to 15 metres.

Due to the poor conservation of the wood, the size and morphology of the root systems of the different tree species could not be established exactly. As with regards to shape, it seems that the trees did not root deeply but instead formed a shallow horizontally extended root system. Dendrochronological research has shown that most of the dated oaks and all of the dated ash trees germinated after 1950 BP (Sass-Klaassen \& Hanraets, 2006). Radiocarbon analysis has dated the beginning of peat growth to around the beginning of our Era. This means that most of the oaks and ashes germinated on the peat. Yet the roots did make contact with the mineral subsoil, as was visible in the studied profile walls and excavation level in which a few tree falls were present.
The tree trunks were randomly distributed in terms of direction (see Fig. 11). Consequently, their death could not be attributed to one specific event like a storm.

\section{Vegetation structure}

An attempt was made to reconstruct the structure of the vegetation. The recovered trunks were on the whole straight. There were no massive limbs recognized close to the stem base indicating a low crown; multiple trunks were absent. Although many morphological features were lost through time, the recovered wood shows all characteristics that belong to trees (mainly oak and ash) that grow in a closed stand. The same picture emerged from the spatial distribution of the trees in all four trenches. From the position of the wood remnants, combined with the species, the total number of trees in the excavated area was calculated. It was estimated that 94 trees grew on an area of 1273 square meters. This would allow each tree an average of $13.5 \mathrm{~m}^{2}$. This approach is a rough one, as the life-span of individual trees was not taken into account and certainly not all of the trees grew simultaneously. On the other hand the dendrochronological study showed that most of the dated trees grew between AD 100 and 300 (1850 - $1650 \mathrm{cal}$. BP) (Sass-Klaassen \& Hanraets, 2006). Moreover, as a result of poor conservation, part of the trees, especially young ones and trees in the upper layers, will have been decayed without leaving any trace. Despite these reservations, the morphological information of the trees and the overall spatial distribution still suggest that during the investigated period this area bore a closed woodland. Given the homogeneous distribution of the recovered remnants and their identified species this woodland covered the whole area of the excavation, i.e. at least three hectares.

\section{From wood remnants to pollen and to vegetation}

Palynological research aims to transform information of the preserved pollen composition into a vegetation picture. One of the key questions is the selection of species that belong to a vegetation unit. For this aim generally Iversen diagrams are used (Iversen, 1947, cited in Janssen, 1974 and Fægri et al., 1989). In an Iversen diagram a fixed number of pollen of trees, shrubs and herbs of dry land are counted in each sample, the so-called upland pollen sum. This approach is based on the assumption that the 'upland' pollen has a regional provenance, in contrast to the pollen of marsh and aquatic plants, which is believed to be of local origin. In this respect the pollen of alder, willow and birch are considered to represent the local vegetation, while the pollen of oak, ash and elm attribute to the regional upland vegetation. In the case of ZwolleStadshagen, this would mean that ash, maple and elm should be given regional instead of local status. However, the identification of the wood remnants has shown that this assumption is erroneous. Therefore in this case these species have been placed in the pollen diagram in the group of local woodland 
species. By adding these trees to the group of the local woodland species, it became clear that 'regional' pollen was virtually absent. The local vegetation, largely consisting of trees, has obstructed most of the regional pollen rain. The palynological evidence, therefore, almost entirely reflects the local vegetation.

\section{Discussion}

\section{The time frame}

${ }^{14} \mathrm{C}$ analysis and dendrochronology were used to derive a time frame that enables to link the different archives and to come up with an integrated analysis of the development and environmental characteristics of the wetland wood at ZwolleStadshagen.

The ${ }^{14} \mathrm{C}$ results are already given in Table 1 . The dendrochronological results support these results by showing that the oaks grew between BC 131 and AD 567 (2082 - 1383 cal. BP) the ashes started later around $\mathrm{AD} 58$ with the last ash dying in $\mathrm{AD} 527$ (1892 - 1423 cal. BP). From the tree-ring analysis it became obvious that both oak and ash were slow-growing and went through alternating phases of normal and depressed growth. Obvious shifts in population dynamics, i.e. germination and dying-off, were synchronous with abrupt growth depressions and occurred between AD 58 and AD 90 (1892 - 1860 cal. $\mathrm{BP})$ at the beginning of the establishment of ash, around $\mathrm{AD}$ 300 (1650 cal. BP) and shortly before the woodland collapsed starting at about AD 530 (1420 cal. BP) (Sass-Klaassen \& Hanraets, 2006). Both sets of radiocarbon and dendrochronological datings have been combined and the following time frame could be set (Fig. 12, columns A and B).

The base of the sandy humous material accumulated on top of the drowned, originally well-drained, podzol was formed between 1630 and 1510 BC (3580 - 3460 cal. BP). After continued accumulation of organic material mixed with sand blown-in from surrounding ridges, soil formation occurred resulting in leached humic acids at the dated depth about 150 years later.

The base of the peat is dated between $\mathrm{AD} 6$ and $\mathrm{AD} 102$ (1944 - 1848 cal. BP). Peat growth started perhaps slightly earlier, as the sample was collected in the peat proper, one centimetre above its lower boundary. Peat formation enabled

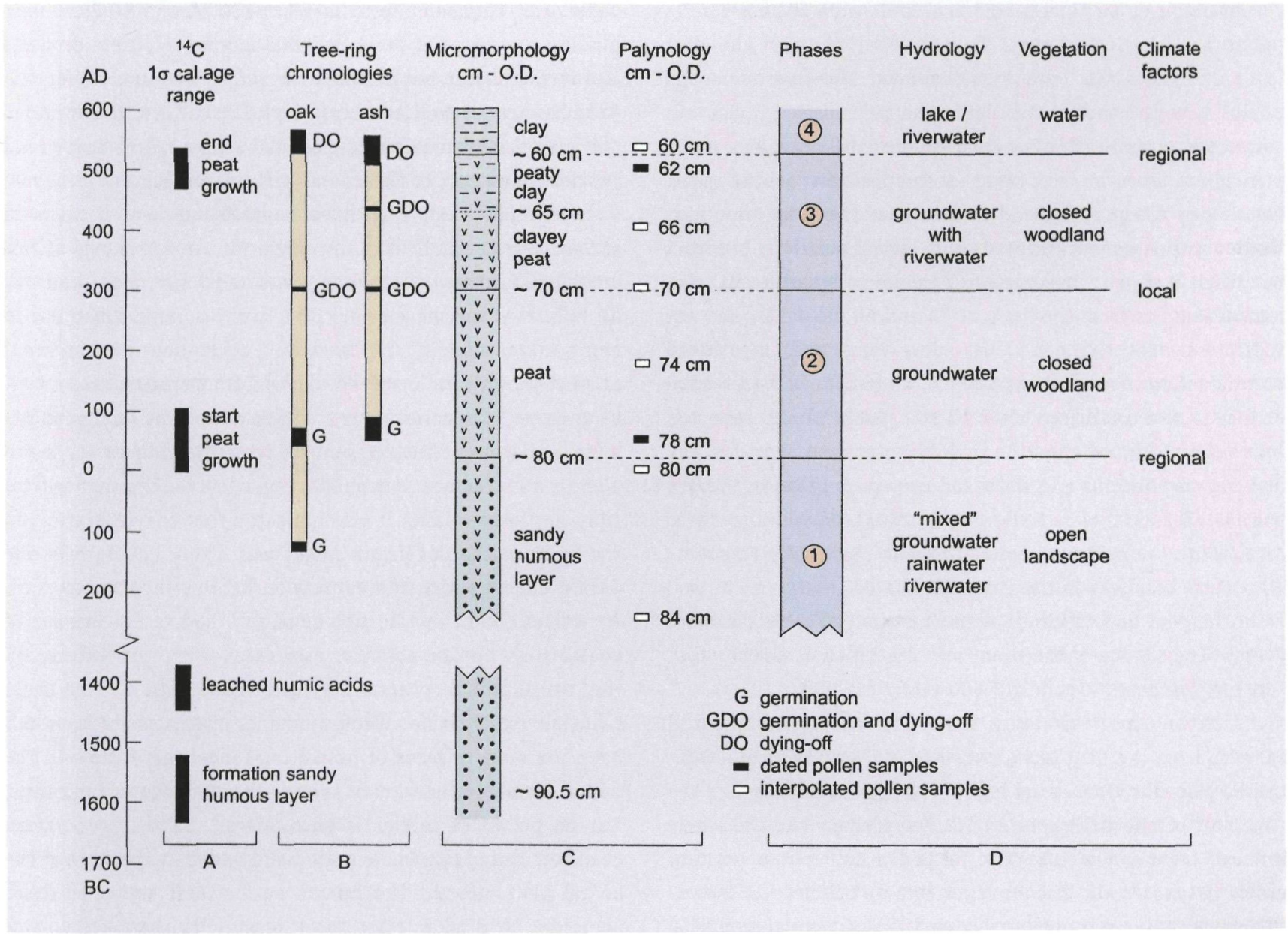

Fig. 12. Reconstructed time frame showing the successive phases in the development of the past landscape and vegetation. A: absolute datings obtained by ${ }^{14} \mathrm{C}$ analyses; $B$. absolute datings obtained by dendrochronology; C. correlated time-depth data of the detected layers and pollen samples; $D$. phases with their reflection in hydrology and vegetation and scale of changes between the phases. 
the preservation of the vegetation, especially wood remnants and pollen. The first oaks that were preserved in the peat and could be dendrochronologically dated had already started to grow around BC 130 (2080 cal. BP) in the, at that depth rather peaty, sandy humous layer. The woodland collapsed abruptly after a major growth depression starting around AD 530 (1420 cal. BP) (Sass-Klaassen \& Hanraets, 2006). This date is in line with the end of the peat growth dated radiometrically between AD 474 and AD 538 (1476 - 1412 cal. BP).

The results of the micromorphological and palynological research were correlated to this time frame (see Fig. 12, column C). The ${ }^{14} \mathrm{C}$ sample at the base of the peat corresponded with the palynological sample taken at $78 \mathrm{~cm}$ depth. The palynological sample collected at $80 \mathrm{~cm}$ depth marked the start of the peat growth and the end of the accumulation of the sandy humous layer, and can be placed in the first half of the first century $\mathrm{AD}$. The ${ }^{14} \mathrm{C}$ sample at the top of the peat corresponded with the palynological sample taken at $62 \mathrm{~cm}$ depth and was collected just below the sharp transition from the peaty clay to the pure clay deposit. The beginning of the deposition of the pure clay layer can be placed in the first half of the sixth century AD.

Lithological, micromorphological and palynological results led to the conclusion that about halfway through the peat layer, at $70 \mathrm{~cm}-0 . D$., conditions changed. Micromorphological analysis showed that at this depth the peat started to contain some clay, an indication for the influence of an active stream, coinciding with an increased decomposition of the peat. Palynology too provided indications that the peat growth at that depth was interrupted and decomposition occurred resulting in a poor preservation of pollen. The other palynological samples from the peat, at 74 and $66 \mathrm{~cm}-0 . D .$, did not indicate marked changes in peat development. As mentioned above, dendrochronological results pointed to a substantial change in site conditions after AD 300 (1650 cal. BP) reflected by a major GDO (germination and dying-off) event in the oak and ash populations and a marked growth depression in both species (Sass-Klaassen \& Hanraets, 2006). Combining these results and taking into account that the reconstructed events all occurred midway in the absolutely dated time frame as well as in the peat deposition, it seems justified to correlate these events. The change of the conditions identified at $70 \mathrm{~cm}-0 . D$. can then be dated around AD 300 (1650 cal. BP).

Based on this time-depth scale, the other palynological samples from the peat layer, collected at 74 and $66 \mathrm{~cm}-0 . D$., can be placed in the second half of the second century and the first half of the fifth century $A D$ respectively. As the sandy humous layer below the peat formed a continuum without erosional phases and has an at random distribution of blownin sand with a few pure blown-in sand layers, the palynological sample from $84 \mathrm{~cm}$ depth can be roughly placed in the period between 800 and $500 \mathrm{BC}(2750-2450 \mathrm{cal}$. BP).

\section{Development, dynamics and collapse of the wetland wood at Zwolle-Stadshagen}

Based on the time-depth scale reconstructed in the previous section, two phases can be distinguished in the peat development, one from the start of the peat growth in the first half of the first century $\mathrm{AD}$ until approximately $\mathrm{AD} 300$ (ca. 1925-1650 cal. BP), and one from ca. AD 300 till the end of the peat growth in the first half of the sixth century $A D$ (ca. 1650-1420 cal. BP). To place the peat growth in its proper setting four phases in the landscape and woodland development are distinguished (Fig. 12 column D): one before the peat growth, two phases during the peat growth and one afterwards. These phases are discussed below and visualized in Figure 13. The information obtained by all the disciplines involved, is combined and integrated. The starting point was a well-drained podzol developed in aeolian coversand of the Boxtel Formation in a depression between two ridges.

\section{Phase 1. Before the start of the peat growth}

This phase represents the landscape before the start of the basal peat, between approximately $1750 \mathrm{BC}$ and $\mathrm{AD} 25$. Due to a rising groundwater level well-drained podzols were drowned and in the depression between the ridges wetlands developed. Palynological as well as micromorphological results confirmed the presence of some pools and small streams. This system has possibly been part of the inland Vecht delta (Ente et al., 1965; Wolfert, 2001) and may have been abandoned, because of silting up river branches in this delta. The AP percentage of $70 \%$ assumes an open to semi-open woodland with alder and oak as main tree species growing on a moist organic substrate. In this accumulating organic material a continuous random input of wind-blown sand occurred, derived from surrounding coversand ridges. The continuous at random input of sand supports a more open woodland present on somewhat higher spots and along water courses, surrounded by a low herbaceous vegetation, partly moorland. It also indicated that the vegetation on the surrounding coversand ridges was often lacking over the period during which the depression became increasingly wet. As wetter conditions do not generally lead to an absence of vegetation, human activity, associated with agriculture, on the surrounding coversand ridges appears to be the most plausible explanation. Wood remnants of this phase have not been preserved. Traces of human presence were visible in the pollen sample in the form of so-called anthropogenic indicators, but no pollen of cereals is encountered. Sand incorporation occurred during the whole period and ended at the start of the actual peat growth. The human agricultural activities could therefore have taken place for at least 1500 years. 


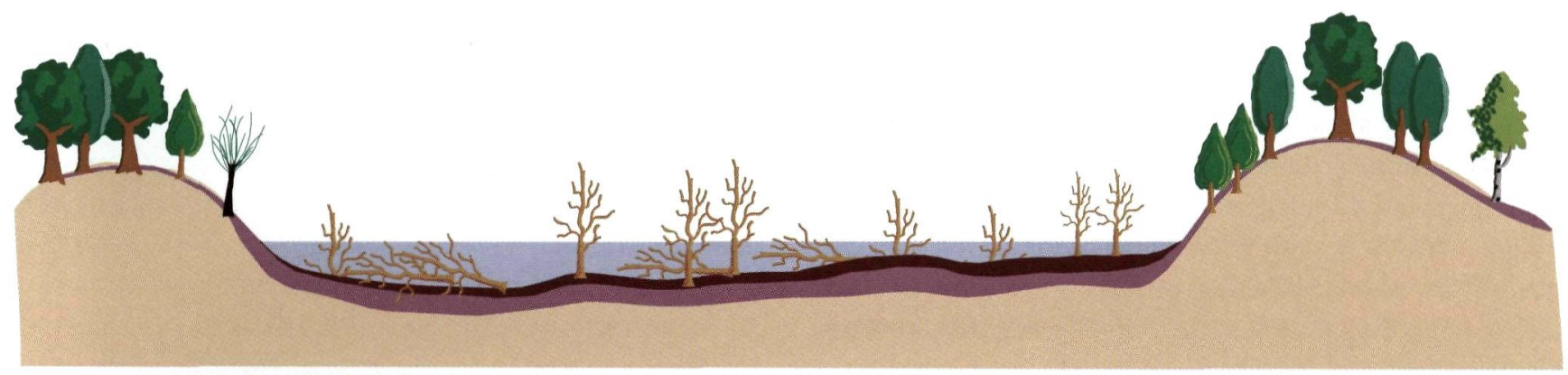

phase $4>\sim$ AD 530

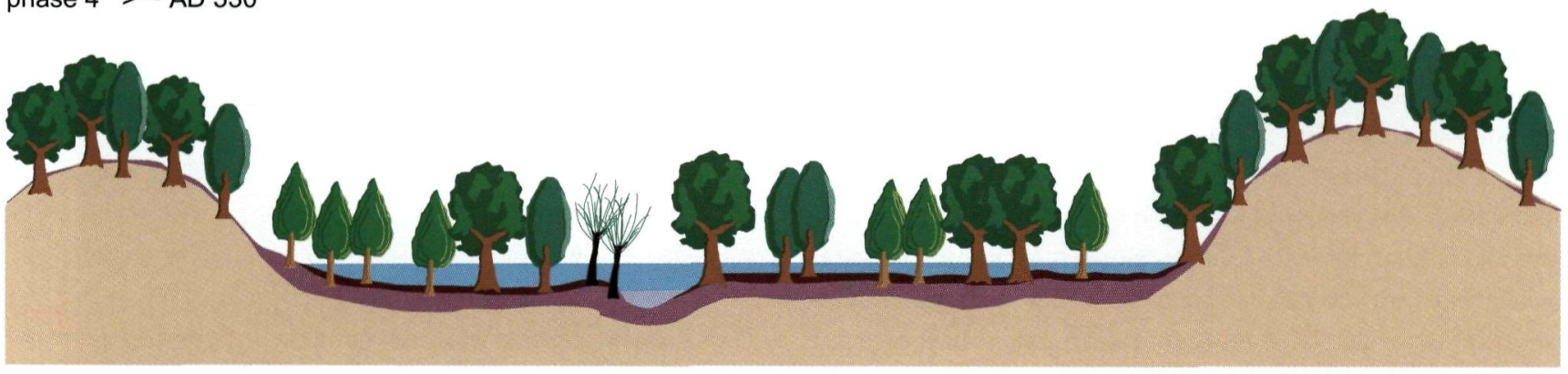

phase $3 \sim$ AD $300-530$

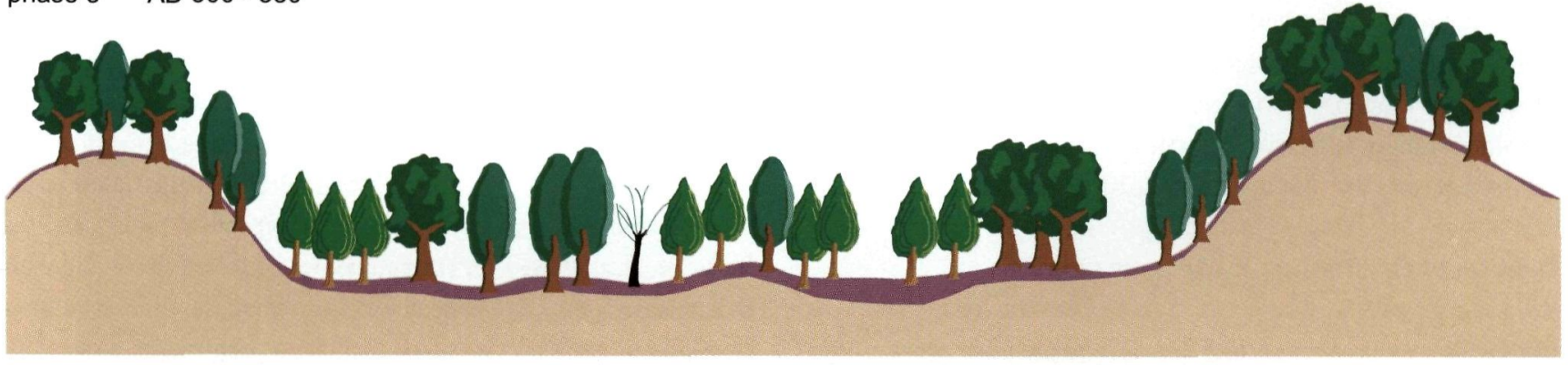

phase $2 \sim$ AD $25-300$

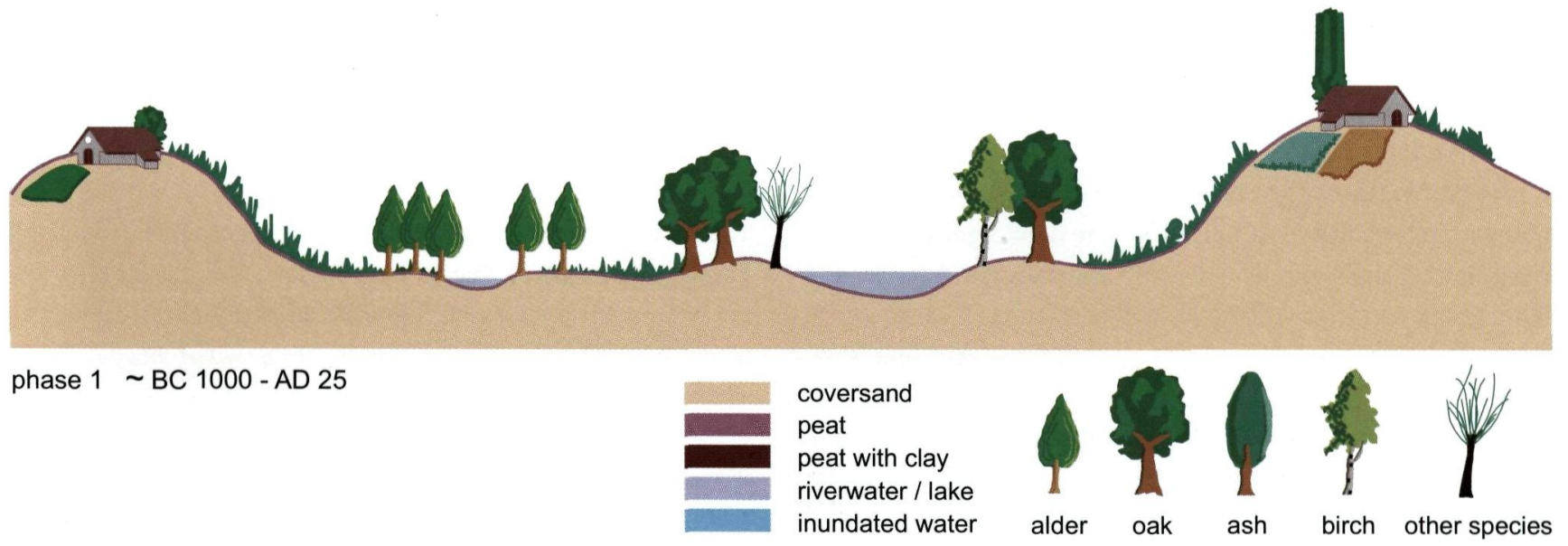

Fig. 13. Visualization of the four distinguished phases in the development of the landscape with its vegetation and woodland. Phase 1: $\sim B C 2000-A D 25$ (ca. 3900 - 1925 cal. BP); Phase 2: AD 25 - 300 (ca. 1925 - 1650 cal. BP); Phase 3: AD $300-530$ (ca. 1650 - 1420 cal. BP); phase 4: > AD 530 (<1420 cal. BP).

\section{Phase 2. First phase of the peat growth}

The first phase of basal peat formation occurred between ca. AD 25 and AD 300 (ca. 1925-1650 cal. BP). When the groundwater level reached the surface the depression became covered with a continuous layer of peat. Decomposition of the peat by bacteria and mesofauna indicated that the $\mathrm{pH}$ was more acid than in the previous phase. Trees grew on the peat, as tree roots are common, with ash, alder and oak as main species. The AP percentage is on average $80 \%$. This percentage is considered to represent a semi-open to closed woodland. In the case of Zwolle-Stadshagen, with a tree density of about 
13.5 tree $/ \mathrm{m}^{2}$, the AP:NAP ratio of $80: 20$ represented a closed woodland. The palynological data and those of the wood remnants lead to different vegetations types. The palynological evidence pointed to an alder carr and those of the wood remnants to an Alno-Padion. Looking more closely at both results the occurring forest type closely resembled an Alno-Padion described by Van der Werf (1991) as the nearextinct Filipendulo-Alnetum Passage et Hofmann 1968, an intermediate between an Alno-Padion and an alder carr. In wetter periods this Filipendulo-Alnetum would assume more the character of an alder carr; in drier periods those of an Alno-Padion. This type of woodland naturally occurs on peaty clay soils or peat containing a small proportion of clay and important tree species are alder and ash. In this forest type the water level fluctuates. The peat would decompose in better drained periods and accumulate during periods with higher water levels. Data on its natural occurrences are practically nonexistent. Only Bakels et al. (2000) described this vegetation type as an 'ash and alder woodland on a subsoil of eutrophic peat' growing in the twelfth-century in the vicinity of Gouda.

In this phase the ridges became covered with a closed vegetation, probably woodland. No evidence of exploitation of the woodland by man nor of animal foraging was found. In the pollen diagrams anthropogenic indicators were virtually absent.

\section{Phase 3. Second phase of the peat growth}

The landscape in the second phase of the peat growth was formed between ca. AD 300 and AD 530 (1650 - 1420 cal. BP). The woodland peat became periodically flooded as a new freshwater stream started to function in the depression. According to Kuijer \& Rosing (1994) the stream concerned most probably was a new lateral branch of the anastomosing river system in the inland delta of the river Vecht (see Fig. 14). During the inundations thin layers of pure clay were deposited. In between these inundations the peat became increasingly drained and bioturbated by terrestrial worms and mesofauna. Their presence shows that the $\mathrm{pH}$ had increased to slightly acid and even neutral. Towards the top the inundations increased, resulting in increased clay deposition. These changes in site hydrology resulted in a high proportion of unidentifiable pollen. No changes in vegetation type compared to the first phase of peat growth could be traced but conditions for the existence of the Filipendulo-Alnetum Passage et Hofmann 1968 became more pronounced. In the first phase of the peat growth the character of an alder carr could have been more dominant. The ridges, most probably, remained covered by closed woodland.

Here too, no traces of man or animal have been found in the woodland. However, in the pollen sample at $66 \mathrm{~cm}-0 . D$., some rye pollen (Secale cereale) was encountered. This pollen will have been transported with the water and deposited together with the clay. Possibly rye was cultivated on levees in the backlands of this area at the start of the inundations.
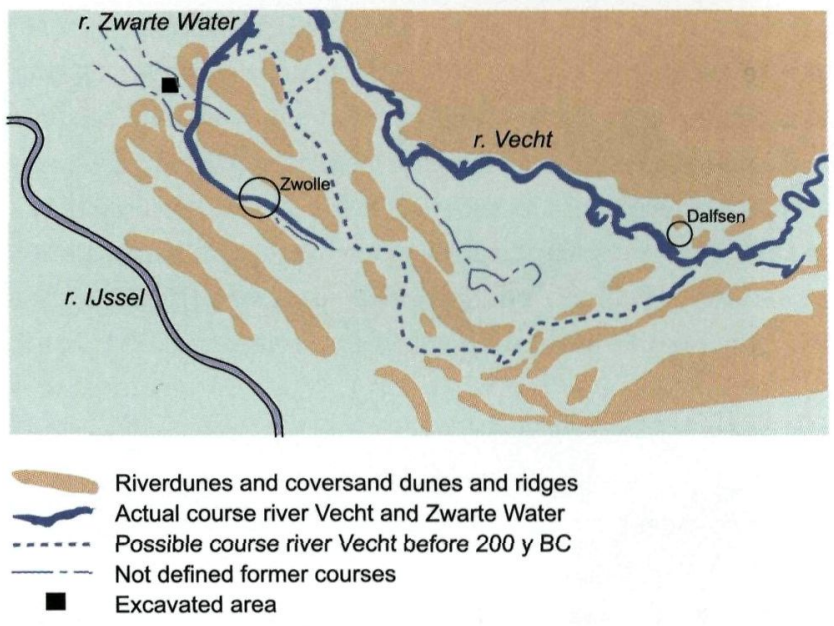

Fig. 14. Former and present river courses in the inland Vecht Delta (extended after Kuijer \& Rosing, 1994).

Phase 4. The end of the peat growth, inundation of the woodland

The landscape after the end of the peat growth, i.e. from ca. AD 530 onwards, changed drastically. The whole depression was inundated, the woodland drowned and a temporary freshwater lake formed. Dendrochronological results show that both the oak and ash populations collapsed abruptly after a major growth depression starting around AD 530 (Sass-Klaassen \& Hanraets, 2006). The peat with its wood remnants became covered by a ca. $40 \mathrm{~cm}$ thick lacustrine deposit of pure clay, whereby the peat with all its organic remnants became compacted and preserved.

\section{Reconstructed landscape with its woodland in its contemporary setting}

The four reconstructed phases in the landscape and woodland development may be due to local factors and restricted to the study area or they may be the result of external factors. In the latter case they could be placed in a wider scope. Three marked changes in hydrological conditions related with the phases in the landscape and woodland development have been identified. These were: (1) a continuous rising groundwater table leading to the growth of the basal peat; (2) the occurrence of a freshwater stream resulting in periodical inundations on one hand and an increased drainage of the top of the peat on the other hand; (3) the complete inundation of the peat, drowning of the woodland and formation of a temporary freshwater lake. These marked changes are discussed below (see Fig. 12, column D).

\section{Rising groundwater table}

The results of the ${ }^{14} \mathrm{C}$ date of the base of the peat fitted well in the extrapolated mean sea level-curve of Van der Plassche 
(1982). Consequently the peat-growth at Zwolle-Stadshagen can be attributed to a regional rise in groundwater level and is a consequence of the general evolution of mean sea level rise in the Holocene (see Fig. 6).

\section{Origin freshwater stream and clay deposition}

Around AD 300 (ca. 1650 cal. BP) a new stream developed in the wetland wood. This was concluded from the presence of thin layers of clay and the rise in $\mathrm{pH}$ observed by micromorphology. This stream most probably belonged to the anastomosing river system in the inland delta of the river Vecht (Kuijer \& Rosing, 1994). During this period both oaks and ashes showed a shift in population dynamics as well as an abrupt growth depression indicating a sudden change in ecological site conditions (Sass-Klaassen \& Hanraets, 2006). Even if this shift in population dynamics is not obvious in the NW European bog-oak record, a change towards wetter climate conditions around $\mathrm{AD} 300$ has been reported for other wetland sites in NW Europe (Leuschner \& Sass-Klaassen, 2003). However, the origin of a new stream with input of sediment could also have been a local event.

Inundation of the peat, drowning of the woodland and formation of a temporary freshwater lake

The composition of the clay on top of the peat, almost only $<2 \mu \mathrm{m} \varnothing$, is strongly indicative of a lacustrine genesis. A backswamp deposit always contains a substantial amount of silt and fine sand. Presence of a temporary freshwater lake drowning the woodland, therefore, is the most logical interpretation. This characteristic lacustrine deposit has only been found in Zwolle-Stadshagen, Stadsbroek and in the builtup area on the north side of the town of Zwolle. At the same time peat growth stopped not only here but also in a wider area. Ente (1986) documented that about $12 \mathrm{~km}$ NW of ZwolleStadshagen peat growth stopped at AD $520 \pm 50$ year ( $\mathrm{GrN}$ 7492) whereby the peat became covered by a clay deposit. Most of the oaks and ashes died between AD 530 and 540 after showing dramatic growth depressions which are synchronous with those of oaks from many sites in NW Europe, including Ireland (Leuschner et al., 2002, Baillie, 1994; 1999).

The fact that after AD 530 many trees on different wetland sites in NW Europe died or showed prolonged growth depressions (Leuschner et al., 2002, Sass-Klaassen \& Hanraets, 2006) leads to the conclusion that the inundation of the depression has to be attributed to a regional factor. The excessive discharge of water was probably the result of a dramatic climate change after a volcano and/or comet event resulting in cold, wet weather for at least 18 years in the northern hemisphere (Baillie, 1994, 1996, 1999; Keys, 1999; Larsen, 2002).

\section{Conclusions}

Each discipline involved contributed essential information that resulted in 1. a detailed reconstruction of the environment before, during and after the period the woodland existed and 2. a detailed reconstruction of the woodland vegetation, its structure and development.

The micromorphological research contributed substantially and offered more precise and new information on the geogenesis and environmental conditions through time. This information cannot be obtained during field surveys, but only by the use microscopic techniques. Its impact is reflected in the presented soil genesis and soil formation, waterlevel movements and water quality, the varying ways of decomposition of organic matter and the human impact.

The pollen analyses offered essential information on the vegetation and its ecology before and during peat growth and confirmed phases of stagnant peat growth also found in the micromorphological and dendrochronological studies. They formed the base of the reconstruction of the woodland vegetation. Combined with the wood analyses some highly interesting results emerged. Firstly, it showed that the local vegetation, a woodland, obstructed most of the regional pollen rain. The pollen reflected almost entirely the local vegetation. Secondly, although reflecting the local pollen rain, the palynological data and those of the wood remnants did not lead to the same vegetation type. The palynological data pointed towards an alder carr; those of the wood remnants to an AlnoPadion. The micromorphological study confirmed environmental conditions of both vegetations, with a dominance for an alder carr in the first phase of the peat growth changing into a dominance of an Alno-Padion in the second phase. It also explained that the pollen quality was poor due to alternating drier and wetter periods coupled with the presence of terrestrial earthworms that mixed most of the upper half of the peat by bioturbation. Moreover mesofauna converted about half of the organic matter in worm excreta inclusive pollen. It is not known whether mesofauna preferably consumes specific pollen, which also can be the case. Thirdly, the AP:NAP ratio of $80: 20$, which assumes a presence of a semi-open to closed woodland, represented in this case a closed woodland. These points have to be taken into account in future research on former woodlands. The pollen analyses combined with wood research supported with micromorphological analyses have lead to a convincing identification of a specific vegetation, the near-extinct Filipendulo-Alnetum, that would not have been possible otherwise.

${ }^{14} \mathrm{C}$ dating and dendrochronology from tree ring series of oak and ash, supported each other very well. The micromorphological results on genesis and soil development and the palynological results on pollen quantity and composition could therefore be correlated without restrictions and a detailed time frame for four different phases in the development of the 
palaeo-landscape with its vegetation c.q. woodland, as presented in the discussion, could be obtained. For this timeframe the results of the local tree-ring site chronologies of oak and ash were used as discussed in Sass-Klaassen \& Hanraets (2006). From these site chronologies it was evident that both oak and ash were growing slow and showed alternating phases of normal and depressed growth. The interpretation of the specific tree-ring pattern in terms of related site factors has been problematic since no modern woodland exists in NW Europe in which oak with this specific growth pattern can be found. By combining the micromorphological and dendrochronological results in this well-planned and coordinated approach, it was possible to correlate the growth depressions in the second phase of the peat growth to the development of a new stream in the wetland wood leading to inundations that could be traced by the deposition of thin layers of clay in the peat.

The human presence traced in the reconstructed landscape was very limited and the results of the disciplines involved were congruent. Besides human presence on the coversand ridges in the intermediate phase before the peat started to grow, no evidence of exploitation of the woodland for its wood by man or of animal foraging was found. Only at the start of the inundations of the peat due to the appearance of a new stream some rye pollen (Secale cereale) was encountered. These pollen most probably were transported by the inundating water and might indicate that rye was cultivated on levees upstream of this area.

The integrated research combined field methods as used in archaeology and soil science with those of a specialized approach. In our case micromorphology, palynology, wood analysis and dendrochronology were combined on an equal basis. This is a new combination of specializations and the strength of this combination is that their results can be combined and compared on the same scales. The chosen integrated approach leads to a comprehensive picture of past environmental changes that could not have been obtained otherwise. No parts of the research could have been omitted as it was precisely the aggregation of the different contributions that permitted the detail of the conclusions that could be drawn and led to the improved understanding of the landscape with its vegetation and human activities of the past.

\section{Acknowledgements}

The study was funded by the Municipal Archaeological Survey of Zwolle, the Ministry of Agriculture, Nature Management and Fisheries, the Netherlands Organisation of Scientific Research (NWO/ALW 750.700.04) and BIAX-Consult. We are indebted to Hemmy Clevis who enabled and stimulated this interdisciplinary research project (Municipality of Zwolle). Dick Schreiber is thanked for the preparation of the high quality thin sections, Bart Makaske for his useful contributions to the discussion on the general evolution of the mean sea level in the Holocene in the IJsselmeer area, Gilbert Maas for his research on former streams in the Zwolle-Stadshagen area, all from Alterra (Wageningen University and Research Centre), Dirk van Smeerdijk and Liesbeth van Beurden for the counting of the palynological samples, BIAX-Consult (Zaandam) and Aleid Bosch, NITG-TNO (Utrecht), for his comments on the draft of parts of this paper.

\section{References}

Andersen, S.Th., 1970. The relative pollen productivity and pollen representation of north European trees, and correction factors for tree pollen spectra. Danmarks Geologiske Undersøgelse Series II, 96: 1-99.

Andersen, S.Th., 1973. The differential pollen productivity of trees. In: Birks, H.J.B. \& West, R.G. (eds): Quaternary Plant Ecology (Oxford): 109-115.

Baillie, M.G.L., 1994. Dendrochronology raises questions about the nature of the AD 536 dust-veil event. The Holocene 4: 212-217.

Baillie, M.G.L., 1996. Extreme environmental events and the linking of the tree-ring and ice-core records. In: Dean, J.S., Meko, D.M. \& Swetnam, T.W. (eds): Tree Rings, Environment, and Humanity. Radiocarbon, Department of Geosciences, The University of Arizona (Tucson): 703-711.

Baillie, M., 1999. Exodus to Arthur: catastrophic encounters with comets. Batsford (London): $272 \mathrm{pp}$.

Bakels, C.C., Kok, R.S., Kooistra, L.I. \& Vermeeren, C., 2000. The plant remains from Gouda-0ostpolder, a twelfth century farm in the peatlands of Holland, Vegetation History and Archaeobotany 9: 147-160.

Behre, K.-E., 1981. The interpretation of anthropogenic indicators in pollen diagrams. Pollen et Spores 23: 225-245.

Birks, H.J.B. \& Gordon, A.D., 1985. Numerical methods in quaternary pollen analysis (London): $317 \mathrm{pp}$.

Bisdom, E.B.A. \& Schoonderbeek, D., 1983. The characterization of the shape of mineral grains in thin sections of soils by Quantimet and BESI. Geoderma 30: $303-332$.

Bradshaw, R., 1991. Spatial scale in the pollen record. In: Harris, D. \& Thomas, K.D. (ed.): Modelling Ecological Change. Perspectives from Neoecology, Palaeoecology and Environmental Archaeology, Papers from the Tenth Anniversary Conference of the Association for Environmental Archaeology held at the Institute of Archaeology, UCL, July 1989: 41-52.

Buurman, P., Pape, Th. \& Muggler, C.C., 1997. Laser grain-size determination of soil genetic studies 1. Practical problems. Soil Science, 162: $211-218$.

Buurman, P., Pape, Th., Reijneveld, J.A., De Jong, F. \& Van Gelder, E., 2001. Laser-diffraction and pipette-method grain sizing of Dutch sediments: correlations for fine fractions of marine, fluvial, and loess samples. Netherlands Journal of Geosciences 80 (2): 49-57.

Clerkx, A.P.P.M., Van Dort, K.W., Hommel, P.W.F.M., Stortelder, A.H.F., Vrielink, J.G., De Waal, R.W. \& Wolf, R.J.A.M., 1994. Broekbossen van Nederland, IBM-rapport 096 (Wageningen): 369 pp.

Eilander, D.A. \& Heijink, W., 1990. Bodemkaart van Nederland 1:50.000. Blad 21 West Zwolle. DLO-Staring Centrum (Wageningen): 165 pp.

Ente, P.J., 1971. Sedimentary geology of the Holocene in Lake IJssel region. Geologie en Mijnbouw, 50: 373-382. 
Ente, P.J., 1986. Het ontstaan van het Marsdiep en de Zuiderzee. Werkdocument 1986-102. Rijksdienst voor de IJsselmeerpolders (Lelystad): $34 \mathrm{pp}$.

Ente, P.J., Haans, J.C.F.M. \& Knibbe, M., 1965. De bodem van Overijssel, de Noordoostpolder en 0ostelijk Flevoland. Stichting voor Bodemkartering (Wageningen): $104 \mathrm{pp}$.

Erdtman, G., 1960. The acetolysis method. Svensk Botan. Tids., 54: 561-564.

Evans, A.T. \& Moore, P.D., 1985. Surface Pollen Studies of Calluna vulgaris (L.) Hull and their Relevance to the Interpretation of Bog and Moorland Pollen Diagrams, Circeae 3: 173-178.

Fægri, K., Kaland, P.E. \& Krzywinski, K., 1989. Textbook of pollenanalysis, 4th edition, (Chichester): $320 \mathrm{pp.}$

Gaillard, M.-J., Birks, H.J.B., Emanuelsson, U., Karlsson, S., Lagerås, P. \& Olausson, D., 1994. Application of modern pollen/land-use relationships to the interpretation of pollen diagrams-reconstructions of land-use history in south Sweden 3000-0 BP. Review of Palaeobotany and Palynology 82: 47-73.

Hicks, S., 2001. The use of annual arboreal pollen deposition values for delimiting tree-lines in the landscape and exploring models of pollen dispersal. Review of Palaeobotany and Palynology 117: 1-29.

I.S.S.S.-ISRIC-F.A.O., 1998. World reference base for soil resources. World Soil Resources Reports 84. F.A.0. (Rome): $91 \mathrm{pp}$.

Janssen, C.R., 1974. Verkenningen in de palynologie (Utrecht): $176 \mathrm{pp}$.

Janssen, C.R., 1984. Modern Pollen Assemblages and Vegetation in the Myrtle lake peatland, Minnesota, Ecological Monographs 54: 213-252.

Jongerius, A. \& Heintzberger, G., 1975. Methods in soil micromorphology; a technique for the preparation of large thin sections. Soil Survey Papers 10 , Soil Survey Institute (Wageningen, the Netherlands): $48 \mathrm{pp}$.

Keys, D., 1999. Catastrophe: an investigation into the origins of the modern world. Century (London): $368 \mathrm{pp}$.

Konert, M. \& Vandenberghe, J., 1997. Comparison of laser grain size analysis with pipette and sieve analysis: a solution for the underestimation of the clay fraction. Sedimentology 44: 523 - 535.

Kooistra, M.J., 1990. The future of soil micromorphology. In: Douglas, L.A. (ed.): Soil micromorphology. Elsevier (Amsterdam) 1990: 1-8.

Kooistra, M.J., 1991. A micromorphological approach to the interactions between soil structure and soil biota. In: Agriculture, Ecosystems and Environment 34: $315-328$

Kooistra, M.J. \& Kooistra, L.I., 2003. Integrated research in archaeology using soil micromorphology and palynology. Catena 54: 603-617.

Kuijer, P.C. \& Rosing, H., 1994. Bodemkaart van Nederland 1:50.000. Blad 21 Oost Zwolle. DL0-Staring Centrum (Wageningen): $175 \mathrm{pp}$.

Lanting, J.N. \& Mook, W.G., 1977. The pre- and protohistory of the Netherlands in terms of radiocarbon dates (Groningen): $247 \mathrm{pp}$.

Larsen, L.B., 2002. The sixth century climatic catastrophe told by the ice cores. In: Environmental catastrophes and recoveries in the Holocene, abstracts conference August 9 - September 2, 2002. Department of Geography \& Earth Sciences, Brunel University (Uxbridge, U.K.): http://www.brunel.ac.uk/ depts/geo/Catastrophes.

Leuschner, H.H., Sass-Klaassen, U., Jansma, E., Baillie, M.G.L. \& Spurk, M., 2002. Subfossil European bog oaks: population dynamics and long-term growth depressions as indicators of changes in the Holocene hydro-regime and climate. The Holocene 12: 695-706.
Leuschner, H.H. \& Sass-Klaassen, U., 2003. Subfossil oaks from bogs in NW Europe as a (dendro)archaeological archive. In: Bauerochse, A. \& Hassmann, H. (eds): Peatlands; Proceedings of the Peatland Conference 2002 in Hannover. Rahden/Westf.: Leidorf, Germany: 210-216.

Makaske, B., Van Smeerdijk, D.G., Peeters, H., Mulder, J.R. \& Spek, T., 2003. Relative water-level rise in the Flevo lagoon (the Netherlands), 5300-2000 cal. yr BC: an evaluation of new and existing basal peat time-depth data. Netherlands Journal of Geosciences / Geologie en Mijnbouw 82 (2): 115-131.

Moore, P.D., Webb, J.A. \& Collinson, M.E., 1991. Pollen Analysis (0xford): $216 \mathrm{pp.}$ Munsell Soil Color Charts, 1975. Munsell Color Company, Inc. (Baltimore, Maryland): $40 \mathrm{pp}$.

Pals, J.P., Van Geel, B. \& Delfos, A., 1980. Palaeoecological Studies in the Klokkeweel Bog near Hoogkarspel (Noord-Holland), Review of Palaeobotany and Palynology 30: 371-418.

Punt, W., 1976. The Northwest European Pollen Flora I (Amsterdam): 145 pp.

Punt, W. \& Clarke, G.C.S., 1980. The Northwest European Pollen Flora II (Amsterdam): $265 \mathrm{pp}$.

Punt, W. \& Clarke, G.C.S., 1981. The Northwest European Pollen Flora III (Amsterdam): $138 \mathrm{pp}$.

Punt, W. \& Clarke, G.C.S., 1984. The Northwest European Pollen Flora IV (Amsterdam): $369 \mathrm{pp}$.

Punt, W., Blackmore, S. \& Clarke, G.C.S., 1988. The Northwest European Pollen Flora V (Amsterdam): $154 \mathrm{pp}$.

Punt, W. \& Blackmore, S., 1991. The Northwest European Pollen Flora VI (Amsterdam): $275 \mathrm{pp}$.

Punt, W., Blackmore, S. \& Hoen, P.P., 1995. The Northwest European Pollen Flora VII (Amsterdam): $275 \mathrm{pp.}$

Reineck, H.E. \& Singh, I.B., 1973. Depositional Sedimentary Environments. Springer Verlag (Berlin): $439 \mathrm{pp}$.

Sass-Klaassen, U. \& Hanraets, E., 2006. Woodlands of the past. The excavation of wetland woods at Zwolle-Stadshagen (the Netherlands): Growth pattern and population dynamics of oak and ash. Netherlands Journal of Geosciences 85 (1), 61-71.

Schweingruber, F.H., 1982. Mikroskopische Holzanatomie. Swiss Federal Institute of Forestry Research (Birmensdorf): $226 \mathrm{pp}$.

Soil Survey Staff, 1999. Soil Taxonomy. A basic system of soil classification for making and interpreting soil surveys. Second edition. USDA-RCS (Washington): $754 \mathrm{pp}$.

Stiboka, 1966. Bodemkaart van Nederland 1:50.000, Blad 27 Oost, Hattum. Stichting voor Bodemkartering (Wageningen): $127 \mathrm{pp}$.

Stortelder, A.F.H., Schaminée, J.H.J. \& Hommel, P.W.F.M., 1999. De vegetatie van Nederland Deel 5. Plantengemeenschappen van ruigten, struwelen en bossen (Leiden): $376 \mathrm{pp}$.

Ten Cate, J.A.M., Van Holst, A.F., Kleijer, H. \& Stolp, J., 1995. Handleiding bodemgeografisch onderzoek; richtlijnen en voorschriften. Deel A: Bodem. Technisch Document 19A, DL0 - Staring Centrum (Wageningen): 222 pp.

Törnqvist, T.E. \& Bierkens, M.P.F., 1994. How smooth should curves be for calibration of radiocarbon ages? Radiocarbon 36: 11-26.

Van de Meene, E.A., 1979. Het ontstaan van de Gelderse IJssel. In. K.N.A.G. Geografisch Tijdschrift, Nieuwe Reeks 13, 3: 202-210.

Van den Bremt, P., Dirkx, J., During, R., Van Geel, B., Kooistra, L. \& Tak, G. 1998: Een stekelig beeld van het Atlantische bos. Landschap 15/4: 245-250 
Van der Plassche, O., 1982. Sea level change and water-level movements in the Netherlands during the Holocene. Mededelingen Rijks Geologische Dienst 36-1: 93 pp.

Van der Plicht, J., 1993. The Groningen radiocarbon calibration program. Radiocarbon 35: 231-237.

Van der Werf, S., 1991. Natuurbeheer in Nederland. Deel 5 Bosgemeenschappen (Wageningen): $375 \mathrm{pp}$.

Van Geel, B., 1978. A Palaeoecological Study of Holocene Peat Bog Sections, based on the Analysis of Pollen, Sporen and Macro- and Microscopic Remains of Fungi, Algae, Cormophytes and Animals. Review of Paleobotany and Palynology, 25: 1-120.

Van Geel, B., Bohncke, S.J.P. \& Dee, H., 1981. A Palaeoecological Study of an upper Late Glacial and Holocene sequence from 'De Borchert', the Netherlands, Review of Palaeobotany and Palynology, 31: 367-448.

Van Geel, B., Buurman, J. \& Waterbolk H.T., 1996. Archaeological and paleoecological indications for an abrupt climate change in the Netherlands and evidence for climatological teleconnections around 2650 BP. Journal of Quaternary Science 11: 451-460.

Van Geel, B., Coope, G.R. \& Van der Hammen, T., 1989. Palaeoecology and Stratigraphy of the lateglacial type section at Usselo (the Netherlands), Review of Palaeobotany and Palynology 60: 25-129.

Van Geel, B., Van der Plicht, J., Kilian, M.R., Klaver, E.R., Kouwenberg, J.H.M., Renssen, H., Reynaud-Farrera, I. \& Waterbolk, H.T., 1998. The sharp rise of $\Delta^{14} \mathrm{C}$ ca. 800 cal. $\mathrm{BC}$ : possible causes, related climatic teleconnections and the impact on human environments. Radiocarbon 40: 535-550.

Vera, F.W.M., 1997. Metaforen voor de Wildernis. Eik, hazelaar, rund en paard, $\mathrm{Ph}$. D. Thesis ('s-Gravenhage): $426 \mathrm{pp}$.

Vera, F.W.M., 2000. Grazing Ecology and Forest History (Oxford): 506 pp.

Wiggers, A.J., 1955. De wording van het Noordoostpoldergebied. Proefschrift, Universiteit van Amsterdam. (Amsterdam): $216 \mathrm{pp}$.

Wolfert, H.P., 2001. Geomorphological change and river rehabilitation. Case studies on lowland fluvial systems in the Netherlands. Alterra Scientific Contributions 6. Alterra Green Wold Research (Wageningen): 200 pp.

Zagwijn, W., 1986. Nederland in het Holoceen, geologie van Nederland. Rijks Geologische Dienst (Haarlem): $56 \mathrm{pp}$.

Zeiler, J.T. \& Kooistra, L.I., 1998. Parklandschap of Oerbos? Interpretatie van het prehistorische landschap op basis van dieren- en plantenresten, Lutra 40: $65-76$

Zuur, A.J., 1954. Bodemkunde der Nederlandse bedijkingen en droogmakerijen. Deel B. Hoofdsamenstelling en andere zgn. chemische bestanddelen van op water gewonnen gronden. Direktie van Rijksdienst voor de IJsselmeerpolders en Landbouwhogeschool (Kampen): 100 pp. 